NBER WORKING PAPER SERIES

\title{
CREDIT, FINANCIAL STABILITY, AND THE MACROECONOMY
}

\author{
Alan M. Taylor \\ Working Paper 21039 \\ http://www.nber.org/papers/w21039 \\ NATIONAL BUREAU OF ECONOMIC RESEARCH \\ 1050 Massachusetts Avenue \\ Cambridge, MA 02138 \\ March 2015
}

Forthcoming in the Annual Review of Economics, doi: 10.1146/annurev-economics-080614-115437. I am greatly indebted to my colleagues Òscar Jordà and Moritz Schularick with whom I have worked on the projects described here. Our work has been generously supported by the Institute for New Economic Thinking, the Volkswagen Foundation, the Bank of England, the Hong Kong Institute for Monetary Research, and our home institutions. At various points we have received support and encouragement from many other scholars and organizations too numerous to mention in full here. I thank the reviewing editor and an anonymous reviewer for useful suggestions that have improved the article. For helpful interactions that have served to guide and sharpen my thinking, I thank Michael Bordo, Claudio Borio, Charles Calomiris, Guillermo Calvo, Steve Ceccheti, Gavyn Davies, Mathias Drehmann, Barry Eichengreen, Joachim Fels, Mark Gertler, Charles Goodhart, Gary Gorton, Andrew Haldane, Charles Haswell, Mervyn King, Andrew Metrick, Atif Mian, Maurice Obstfeld, Adam Posen, Manoj Pradhan, Carmen Reinhart, Vincent Reinhart, Ricardo Reis, Kenneth Rogoff, Julio Rotemberg, David Scharfstein, Amir Sufi, Adair Turner, Martin Wolf, and Michael Woodford. All errors are mine. The views expressed herein are those of the author and do not necessarily reflect the views of the National Bureau of Economic Research.

NBER working papers are circulated for discussion and comment purposes. They have not been peerreviewed or been subject to the review by the NBER Board of Directors that accompanies official NBER publications.

(C) 2015 by Alan M. Taylor. All rights reserved. Short sections of text, not to exceed two paragraphs, may be quoted without explicit permission provided that full credit, including $\bigcirc$ notice, is given to the source. 
Credit, Financial Stability, and the Macroeconomy

Alan M. Taylor

NBER Working Paper No. 21039

March 2015

JEL No. E02,E31,E42,E44,E51,E58,F32,F42,G01,G20,G28,N10,N20

\title{
ABSTRACT
}

Since the 2008 global financial crisis, and after decades of relative neglect, the importance of the financial system and its episodic crises as drivers of macroeconomic outcomes has attracted fresh scrutiny from academics, policy makers, and practitioners. Theoretical advances are following a lead set by a fast-growing empirical literature. Recent long-run historical work has uncovered a range of important stylized facts concerning financial instability and the role of credit in advanced economies, and this article provides an overview of the key findings.

\author{
Alan M. Taylor \\ Department of Economics and \\ Graduate School of Management \\ University of California \\ One Shields Ave \\ Davis, CA 95616-8578 \\ and NBER \\ amtaylor@ucdavis.edu
}


Normal credit may increase indefinitely; but it can never increase dangerously. Abnormal credit, on the contrary, is perilous in any quantity, exactly because it is of a wholly different kind.

$$
\text { - Laughlin (1902, p. 23) }
$$

Control of credit conditions is always easier before a boom has commenced in earnest. When that has once happened, to prevent its development to a stage ultimately leading to a reaction, and to prevent the reaction running its full course, are both difficult.

- Macmillan Committee (1931, p. 131)

\section{INTRODUCTION}

The global financial crisis of 2008 was fundamentally a credit crisis on a massive, international scale. Nothing remotely like it had been seen since the 1930s. As the world still grapples with this event, from its origins to its aftermath, a dramatic rethinking has been taking place in the so-called advanced economies. Without doubt, many deep questions raised by this unexpected and costly financial disturbance remain unanswered in government, policy, and financial circles, where many of the shocks are still being felt. But research programs in economics have also been overtaken by events. Where do we stand, and what fresh evidence can guide us?

One way to frame an interest in and an understanding of the crisis, within and outside academe, is to start by asking which prior assumptions were exposed by events, how they were found wanting, and what damage this did. Summarizing his recent book The Shifts and the Shocks, Wolf (2014) of the Financial Times pinpoints the essential delusion in the advanced economies: ${ }^{1}$ In short, we did not think something like this could happen. This mistaken belief had two flawed ingredients. First, we saw the chances of a financial crisis as almost impossibly remote-we thought these events happened to others, like emerging markets, but not to us. Second, even if we did admit some tiny risk of crises, we thought they would not be too painful: We could cope and clean up satisfactorily using the policy tools and skills at hand. All seemed well, and faith rested on the Great Moderation, inflation targeting, policy rules, financial development, efficient 
markets, and a slew of institutional reforms. But after hubris came nemesis: Wolf argues that the huge costs of the crisis-lost output, slow growth, unemployment, insecurity, etc.-mean that there is a heavy price to pay. Now the elites, the policy makers, but also the economists have ended up discredited, diminished, and widely distrusted.

If this bleak postmortem is correct, what can restore intellectual credibility? Seeing the social costs of these macroeconomic crises, and with extra doses of humility and the scientific method, we might at least avoid making the same mistakes again. A vigorous recrudescence of macrofinancial economic research is now seeking better evidence and new ideas that respond to the perceived shortcomings and complacency built into the precrisis worldview. Of particular interest, the inductive approach has risen in importance, and new empirical findings from history have emerged, which can strengthen arguments beyond a reliance on introspection and the deductive approach alone. So although new and improved theories are essential, they may prove more resilient next time around if they are rooted in facts. Indeed, a better knowledge of the historical record could have led us to a very different understanding in the run-up to the 2008 global financial crisis. Fortunately, there is now a greater appreciation of the value of broader perspectives, and this article reports on a new stream of work from an empirical project in macrofinancial history that is part of the new research agenda.

\section{THE AGE OF FINANCIAL INSTABILITY}

In what follows, set in the context of a substantial body of past and current work by many other scholars, I lay out the findings from an ongoing macrofinancial economic history project over the past five years that provides new data and analyses to exhaustively study credit and financial crises, compile relevant stylized facts, and investigate their causes and consequences in the entire modern history of the advanced economies since $1870 .^{2}$

Arguably, the two issues that should be at center stage in such work are those just highlighted above as the key flawed assumptions prior to the crisis: the misperceptions as to the expected likelihood and the expected costs of financial crisis events in advanced economies. So can careful empirical work based on history provide us with better estimates of these key measures? 
We start with a look at simple unconditional estimates, but because financial crises are rare events, it is obvious that reliable estimates of these expected values are impossible in small samples using conventional, short-horizon, contemporary macroeconomic data sets. While a recession occurs perhaps once every 5-10 years, a financial crisis happens on average only every $15-20$ years. That amounts to five or six crises per century, meaning that robust statistical inference requires a data set that is substantially expanded in either the space or time dimension, or both. For this reason, recent research has focused on building larger data sets covering wider samples of advanced economies (15-25 countries) and longer spans of time (more than 100 years).

\subsection{Historical Frequency of Financial Crises}

Why do we study financial crises, and what are they? We start by taking for granted that financial crises are not normal events and that they are therefore worthy of special study. That may not be a given, but as demonstrated in the rest of the article, it can be easily shown that they are indeed highly unusual as judged by a number of quantifiable criteria, should the readers fail to be persuaded by the outturn of events they have witnessed since 2008 .

For quantitative purposes, a financial crisis, at its simplest, is a binary on-off event. Although more refined definitions could be implemented in principle, for example, based on the intensity of the crisis, such approaches have not yet been found workable. But even to study the frequency of binary financial crisis events, and ultimately model their probability, we need a satisfactory and agreed-upon definition of what constitutes a financial crisis.

Some of the most important work done in the classification of financial crisis events has unsurprisingly originated from the World Bank and the International Monetary Fund, including recent well-known studies by Laeven \& Valencia (2008, 2012) and going all the way back to seminal works by Caprio \& Klingebiel (1996, 2002). In their pioneering study, Bordo et al. (2001, p. 55) follow a standard definition in this literature to define financial crises as "episodes of financialmarket volatility marked by significant problems of illiquidity and insolvency among financial-market participants and/or by official intervention to contain those consequences." This is sometimes a judgment call, but most subsequent 
works in economic and financial history (e.g., Reinhart \& Rogoff 2009) built upon the same approach, although for some countries and episodes different authors may disagree about whether an event counts as a crisis. I adopt the same criteria in this article, using a standard indicator definition based on the above literature that takes a value of $I$ in the first year when a financial crisis event occurs, and o otherwise. $^{3}$

Using the above definition, Figure 1 shows the historical annual frequency of financial crisis events in the world since 1800 , drawing on the Reinhart-Rogoff event classification for the broadest sample of countries, for both the advanced (high-income; $n=23$ ) and the emerging/developing (middle- and low-income; $n=44$ ) groups. Some features of the data stand out. There were no financial crises recorded in emerging markets before the 1860s, but this reflects in part missing data and small samples; it also reflects the relative financial underdevelopment of poorer countries at that point in history, which left them with insufficient financial infrastructure to cause any crisis of macroeconomic scale. After that, over the long sweep of history, the average probability of being in a financial crisis was small, but not negligible, and was at a similar level of approximately $6 \%$ for both groups after 1870 . In contrast, advanced economies have been experiencing financial crises almost continuously since 1800 (indeed, the first modern financial crisis was arguably the 1797 banking and currency crisis in Britain). Crises have not occurred uniformly, and there have been spikes here and there, especially at times of globally synchronized distress, such as 1929 and 2008, and at lesser peaks, such as 1890 and 1907. The one exception was the postwar oasis of calm seen from the 1940s to the early 1970s, coinciding with an epoch of the financial repression of domestic banking systems in the post-1930s (e.g., high capital requirements, strict regulation and supervision) and restrictions in the Bretton Woods era on cross-border capital flows (i.e., exchange controls). In those years, the number of crises in emerging markets was only two or three, and in advanced economies, there were exactly zero.

A few key takeaways emerge from these data. First, financial crises are not black swans but are rare events: First, for the typical country, they occur every 1520 years on average; thus, we need a large sample of countries and time periods to do serious empirical work. History matters. Second, in the long run, the frequency of financial crises has actually not been that different between advanced 
Figure 1: The percentage share of countries worldwide experiencing the onset of a financial crisis in each year since 1800 for both the advanced (high-income) and emerging (middle-and low-income) groups of economies. Figure reproduced from Qian et al. (2011).

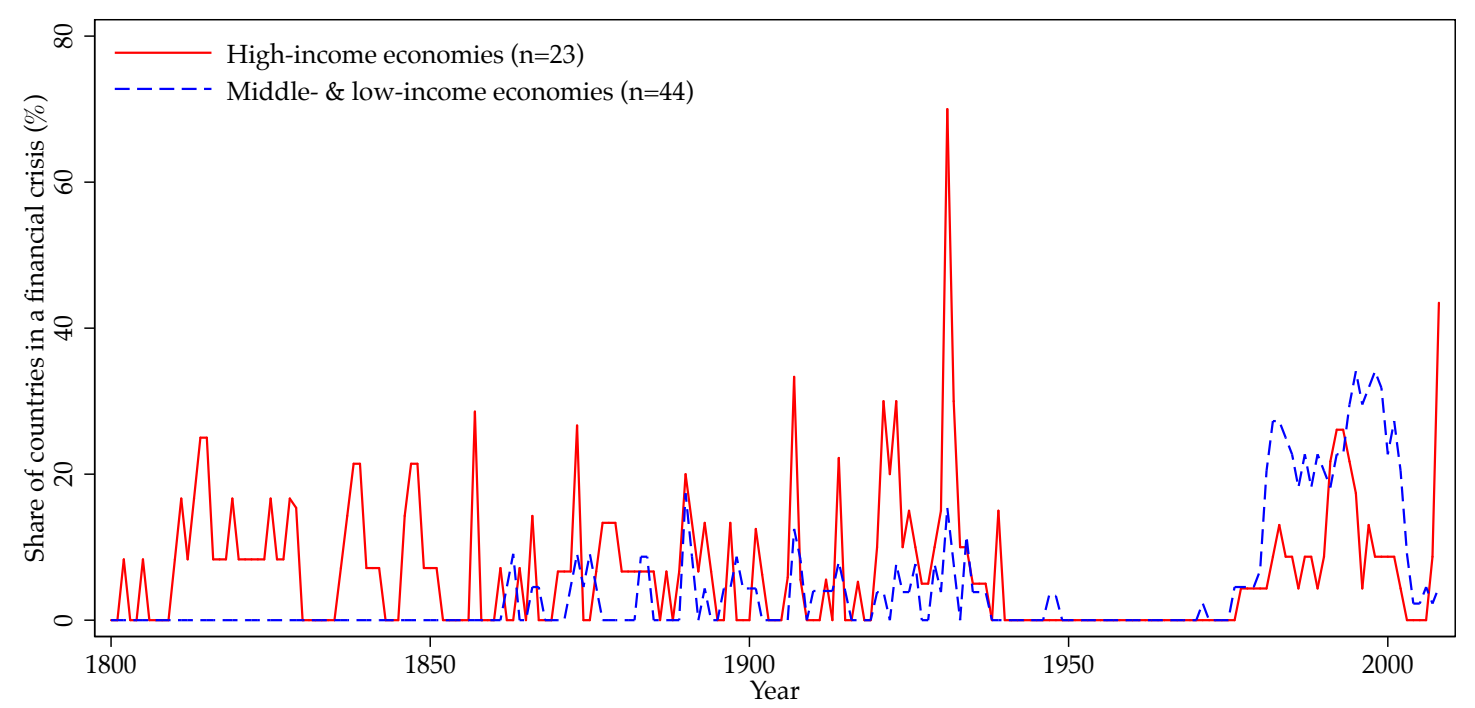

and emerging economies; the two groups of economies are not so different after all, and it was quite complacent to imagine that the advanced world had escaped from financial crisis risk. Third, the immediate decades following World War II were an unusually and deceptively calm era without any financial crises, creating a false sense of security. For some special historical or institutional reasons, it may have been a period of unusually stable finance-capitalism dynamics, as compared to the rest of modern macroeconomic history since the early nineteenth century.

\subsection{Historical Costs of Financial Crises}

The above evidence shows that financial crises have a frequency that is low but not negligible. But they have recently become a focus of intense interest because of their many distinctive characteristics - most particularly because they are now known to be associated with significantly worse economic performance in the short to medium term. The aftermath of the 2008 crisis quickly focused attention on this issue because these cumulated costs seem worryingly high, prompting the question as to what explains the costs and thus what steps might mitigate them.

It is well known that emerging-market economies often suffer painful reces- 
sions after financial crisis events (Kaminsky \& Reinhart 1999, Hoggarth et al. 2002, Cerra \& Saxena 2008, Reinhart \& Rogoff 2009). Of course, it is then natural to wonder if these empirical regularities merely reflect something different about the fragility and volatility of emerging economies, for institutional or other reasons (Acemoglu et al. 2003). Indeed, after the 2008 global financial crisis, policy makers in advanced countries at first invoked an exceptionalism argument to downplay concerns about the likely costs of the crisis relative to typical emergingmarket cases. This excuse became unpersuasive, however, as the sluggish recovery dragged on.

The rest of this article focuses exclusively on the historical experience of the advanced economies to sharpen the evidence for this group while averting any risk of complaints about the inappropriate pooling of advanced and emerging subsamples. This approach can pay off provided one takes a longer historical view so as to develop a sample size sufficient to deliver statistical power. ${ }^{4}$

Focusing on the historical recession experiences in our sample, Figure 2 documents the basic stylized facts on the costs of financial crisis recessions, compared to the baseline case of normal recessions, using the most recent and comprehensive sample of advanced-country data. Following Jordà et al. (2013a), we start by applying simple event-study methods to compute average unconditional recovery paths following what we call a normal recession $(N)$ and a financial crisis recession $(F)$. To fix ideas, we can think of the N's as the control group and the $F^{\prime}$ s as the treatment group. We define the latter as a recession with a peak most closely coincident with a financial crisis, plus or minus two years; the former are all other cases. The figure shows unconditional means of log real GDP per capita relative to a peak out to a five-year horizon for all recessions and recoveries since 1870 in a sample of 17 advanced economies, covering 223 recession events in total. The country sample consists of Australia, Belgium, Canada, Denmark, Finland, France, Germany, Italy, Japan, the Netherlands, Norway, Portugal, Spain, Sweden, Switzerland, the United Kingdom, and the United States, and events in or close to the two world wars are excluded. Roughly three in four of these recession events are normal recessions, and one in four are financial crisis recessions. ${ }^{5}$ Cyclical peak years are denoted year o and were assigned using the Bry \& Boschan (1971) algorithm applied to real GDP per capita; they line up with narrative chronologies of recession dates where available. 
Figure 2: The unconditional average path of real GDP per capita relative to the level in the peak year of the recession in both normal and financial crisis recessions in advanced economies for the (a) full, (b) pre-World War II, and (c) post-World War II samples. Author's calculations are based on data from Jordà et al. (2013a). Abbreviation: CI, confidence interval.

(a) Full sample $(\mathrm{n}=223)$

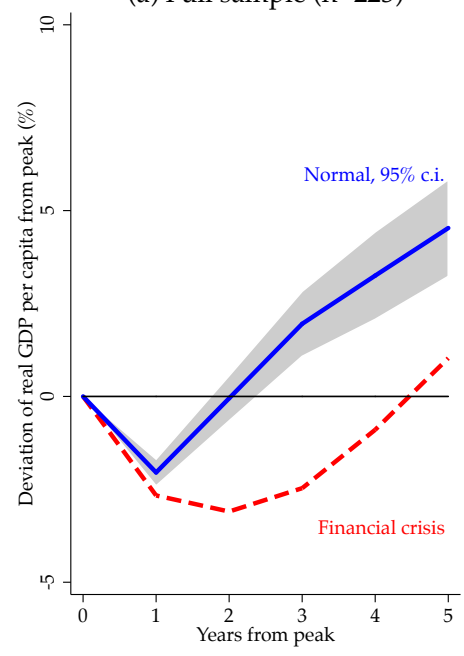

(b) Pre-WW2 (n=156)

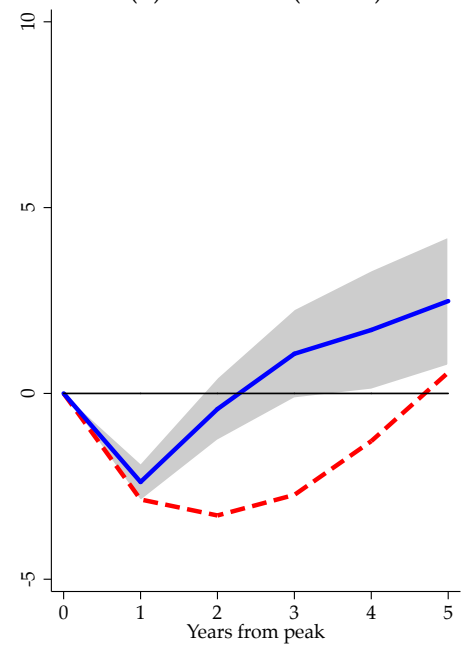

(c) Post-WW2 (n=67)

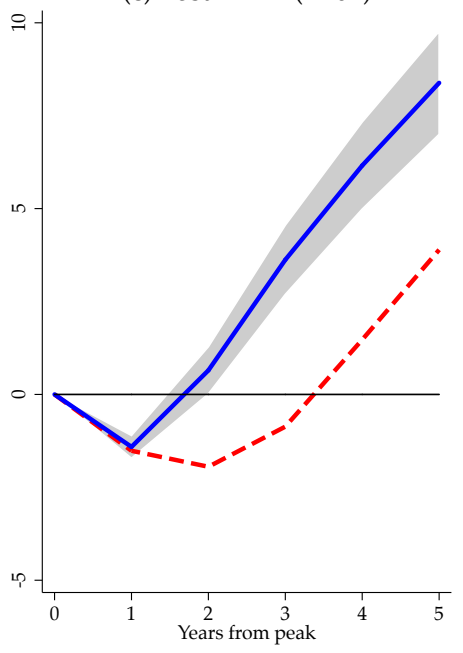

Figure 2a shows the results for all years. Normal recessions are mild on average; they have negative growth for one year, with a loss of approximately $2 \%$ in real GDP per capita. Growth then resumes at a rate of approximately $1.5 \%$ per year out to year 5 , leaving real GDP per capita on average approximately $4 \%$ above its previous peak. Financial recessions are strikingly different, and much more severe on average; they have negative growth for two years, with a total decline of approximately $3 \%$ in real GDP per capita. Growth then resumes at a rate of about approximately $1 \%$ per year out to year 5 , leaving real GDP per capita on average at about the same level as its previous peak. Formal statistical significance tests confirm that these paths are different after year 1 .

Figure $2 b, c$ breaks these paths down for the pre- and post-World War II samples, respectively. Before World War II, the paths are flatter; this results from weaker growth in that era in all years, plus the inclusion of the Great Depression in the sample. After World War II, trend growth is faster. However, the same basic patterns hold true as in the full sample: The financial crisis recessions exhibit much more adverse recovery paths compared to those of the normal recessions. 
In fact, this difference seems to have become more extreme over time: In Figure $2 \mathrm{~b}$, the two pre-World War II paths almost converge by year 5 , and are within $2 \%$ of each other, but in Figure 2c, the two post-World War II paths remain far apart, with a difference of $4-5 \%$ still in year 5 .

Figure 3 reinforces the argument that financial crisis recessions are quite atypical phenomena as compared to normal recessions, as seen by the average unconditional paths for real investment per capita, real credit (bank lending) per capita, the Consumer Price Index (CPI) price level, and the short-term (nominal) interest rate, where again the same event definitions are used for the analysis. In the normal case, real investment per capita drops a few percentage points for one year, then picks up, returns to its peak level by year 3, and resumes growth. Real credit per capita continues to grow in all years, as does the CPI price level, and the short-term interest rate is lower for the next five years by approximately 200 basis points. In financial crisis recessions, real investment per capita collapses by as much as $20 \%$ out to year 3 and does not recover even by year 5 ; real credit per capita grows only about half as fast as in the normal case. The CPI price level remains flat for five years, and short-term interest rates are lower for longer, dropping by approximately 400 basis points.

The message from these data is striking. Financial crisis recessions are far deeper and longer than normal recessions. This is true for the distant pre-World War II era of the gold standard and hard money, fiscal orthodoxy, and no bailouts, but it is also true, and to an even greater degree, for the post-World War II era of activist central banks, fiat money, automatic stabilizers, and financial regulation and backstops. Despite many efforts by policy makers to moderate business cycles, not only are the damaging effects of financial crisis recessions still recurring, they bring with them costs as high as before, if not higher.

\subsection{Explicanda}

We now take the stylized facts as given. For over a century, financial crises have been recurring phenomena associated with very costly recessions and other pronounced macroeconomic shocks. Moreover, these crises have not been confined to emerging markets but are as likely to afflict advanced economies too.

Two major questions naturally follow, which have preoccupied economists and 
Figure 3: The unconditional cumulative average path of (a) real investment per capita, (b) real credit (bank lending) per capita, (c) the CPI price level, and (d) the short-term (nominal) interest rate relative to the level in the peak year of the recession in both normal and financial crisis recessions in the advanced economies in the full sample. Author's calculations are based on data from Jordà et al. (2013a). Abbreviations: CI, confidence interval; CPI, Consumer Price Index.
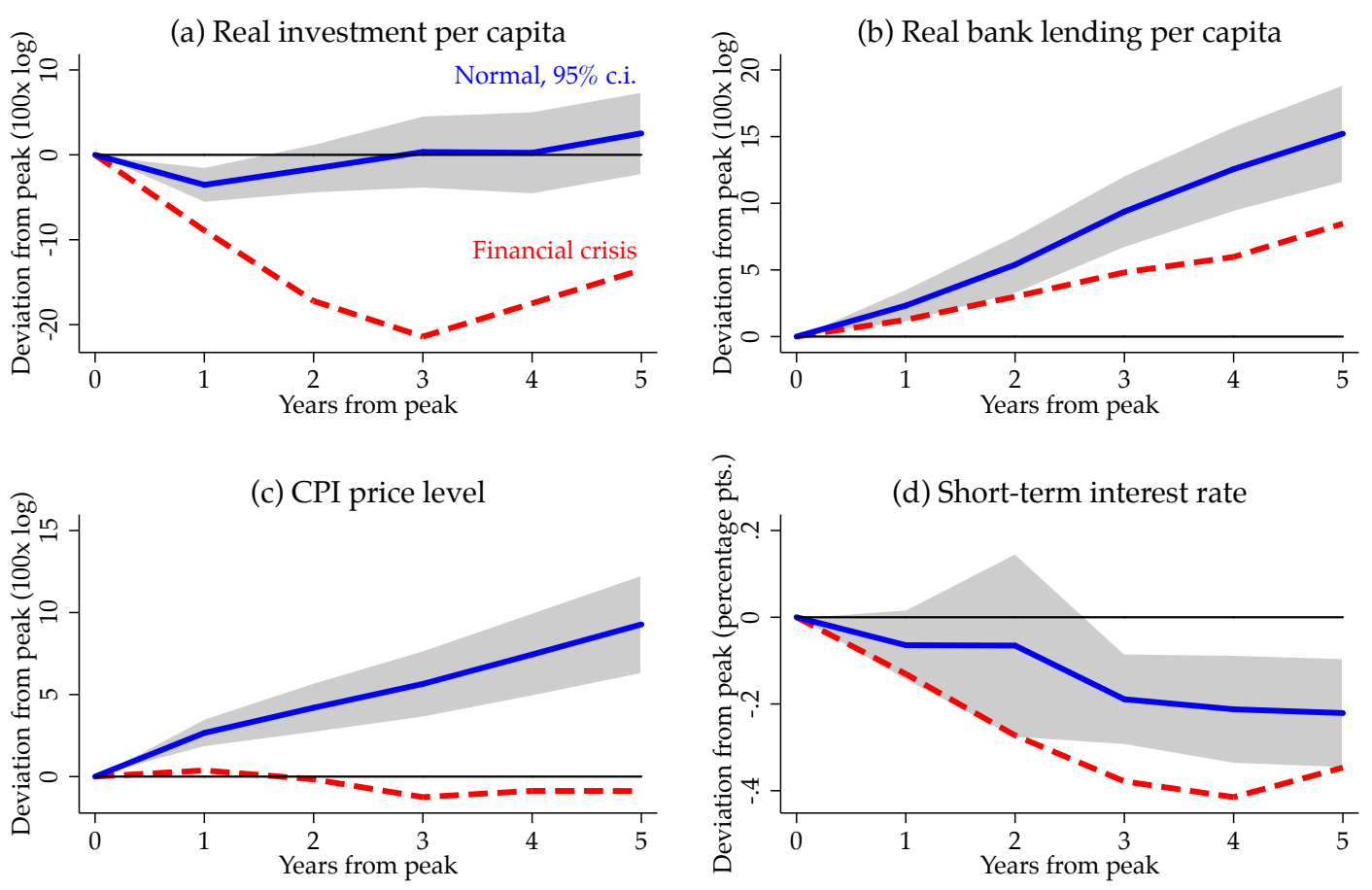

policy makers and which are the focus of the rest of this article. Given the stylized facts based on the unconditional frequencies and sample averages of the sort seen above, we must ask whether further conditioning information can reveal anything about the mechanisms behind the unusual patterns in the data.

First, can we identify any economic factors that can help us understand the probability of financial crisis events occurring (Figure 1)? Are these crises simply random chance, or do some measurable covariate patterns in the macroeconomic environment indicate when we are more or less likely to be at risk of an incipient crisis? Here quantitative historical research has ventured into signal detection and binary classification methods; the key result here will show how credit buildup has always been a powerful warning signal of rising financial instability risk, consistent with contemporary research. 
Second, can we find any factors that can help us to understand why, conditional on a financial crisis event, the subsequent macroeconomic performance is so much worse than that in a normal recession and is characterized by large output losses (Figure 2) and sharp deviations in other macroeconomic variables (Figure 3)? Are the adverse means seen here along the recovery paths simply ineluctable, or are there macroeconomic covariates that can help us account for the distinct shifts between the two paths? Here our quantitative work draws on local projection (LP) methods. The key result will be that overhang from the credit buildup is strongly associated with worse recovery performance, explaining a substantial fraction of the economy's inferior performance after crisis events.

In summary, the evolution of private credit over the business cycle is not uniform over time and space, and significant historical variations in the cyclical behavior of credit help predict both the onset of financial crisis events and their subsequent impact as measured by macroeconomic drag. These findings, documented below, form a platform for ongoing and future research. Gathering more empirical evidence, with finer levels of detail and more robustness, we can sharpen our focus on the key mechanisms at work, hopefully informing the development of more realistic theoretical models at the macrofinance nexus. If so, when the next crisis threatens, we might be a little bit wiser than last time.

\section{THE ASCENT OF CREDIT}

What role, if any, can the study of credit play in explaining the above patterns and providing answers to our two key questions? This is by no means a new area of inquiry, and past macroeconomic debates can certainly inform our search for a better intellectual framework. Although little noted, indeed virtually forgotten, in the run-up to the global financial crisis in 2008, the idea that credit or leverage might shape macroeconomic outcomes is a very old one indeed, but with hindsight, it is obvious that we have witnessed something similar to an old-fashioned banking crisis, although with some distinctive modern features (Gorton 2010, 2012; Gorton \& Metrick 2012). Yet attempts to understand emergent financial fragility go way back, to eighteenth- and nineteenth-century Britain, the first country to enter a phase of capitalistic economic growth built upon a recognizably modern money and banking architecture. From the earliest analyses 
of macroeconomic fluctuations and crises by British scholars, the role of paper credit in a private banking system, and its potentially destabilizing role, was seen as a key mechanism even under a seemingly inelastic monetary regime like the gold standard (e.g., Thornton 1939 [1802]; Attwood 1817; Bagehot 1873; Hawtrey 1913, 1919).

These ideas did not immediately take hold in the face of gold-based orthodoxy, but their time would come, and they would eventually spread far and wide. Referring to the opening quotation from Laughlin (1902) in Section 1, we can see how these views had permeated US economic thinking by the start of the twentieth century. They would underpin the Federal Reserve's financial stability doctrines concerning safe versus unsafe credit from 1923 up until their abandonment in the 1960s (Rotemberg 2014). Similarly, with regard to the other opening quotation, from the Macmillan Committee (1931), over in the United Kingdom, there was a shift in thinking away from Bank Rate and a narrow monetary policy operating under golden fetters toward an awareness of macroprudential concerns arising from credit-driven boom-bust cycles. The committee stated bluntly that "credit is essentially unstable," and this view gained sway in the post-World War II era. Qualitative and quantitative credit controls were then in use by the Bank of England up to the 1970s, when they too were finally cast aside. ${ }^{6}$

Still, notwithstanding some landmark twentieth-century works on debt-driven booms and busts, such as Fisher (1933), Minsky (1986), and Kindleberger (1978), each unduly neglected for years but now suddenly read by so many, the issues of credit and crises were to be largely peripheral in the post-World War II ideas of the economic and policy worlds in advanced economies up to 2008. An exception was the literature on the financial accelerator (Bernanke 1981, 1983; Bernanke \& Gertler 1989; Bernanke et al. 1996), which set out a role for levered finance as an amplification mechanism, even if it placed the driving shocks elsewhere. Still, up to this point in the history of thought, very little large-scale systematic empirical evidence had been presented to supplement a priori theories or a reliance on a few case studies, with few exceptions-most notably the work from the Bank of International Settlements (BIS) by Borio and collaborators exploring the recent post-1970 evidence on credit, asset prices, and financial instability (e.g., Borio \& Lowe 2002a,b; Borio \& White 2004). ${ }^{7}$

Now, in the wake of crisis, the role of credit is much more at center stage, 
with new research focusing on how increasing crisis risk can emerge over time and how deleveraging after a crisis can create a worse recession. In Gorton \& Ordoñez (2014), credit booms can start with lenders paying little effort to get costly information about collateral quality, but over time the quality decays, and financial fragility emerges endogenously and can be triggered by even a small shock. In Eggertsson \& Krugman (2012), the role of heterogeneous agents allows differential responses to shocks among debtors and creditors, leading to adverse aggregate demand conditions, exacerbating liquidity traps in zero-interest rate conditions, building on the empirical analysis and historical account of the Japanese "balance sheet recession" put forward by Koo (2009). As important as new theory, we now also see more systematic empirical work, some intranational and some international. In an influential book, Mian \& Sufi (2014) use crosslocation analyses of US state- and county-level trends before, during, and after the 2008 crisis to convincingly establish a causal link between the levering up of households before the peak, especially via mortgages, and the intensity of the subsequent demand collapse and downturn at the local level (key supporting papers include Mian \& Sufi 2009 and Mian et al. 2013). These authors, like Wolf (2014), draw policy lessons from the instability of credit-based macroeconomic systems. But not all the answers are in when it comes to credit and financial stability, and a tension clearly exists as an academic research agenda slowly gears up and ponders old questions, while a policy world in shock hastens to design and implement new macroprudential policies to stave off the next crisis and close the stable door.

\subsection{Historical Evolution of Credit}

New historical findings complement these new directions in economic research and establish stylized facts for a wide range of countries over a broad sweep of history. After a long and exacting process to gather historical annual data on aggregate credit in advanced economies since 1870, we have discovered that the patterns seen in the recent crisis turn are not unusual at all: They are consistent with the coevolution of cyclical credit and macroeconomic conditions witnessed ever since the birth of finance capitalism approximately 150 years ago. The empirical findings also complement recent studies that have used short, wide 
panels of pooled samples of both advanced and emerging economies, such as Kaminsky \& Reinhart (1999), Borio \& Lowe (2002a), and Gourinchas \& Obstfeld (2012). Our work on the advanced economies in a long, narrow panel maintains a large sample size but minimizes the risks of pooling countries at different stages of development.

The core data we use are long-run time series from 1870 to now for 17 countries for private credit, which is defined as total domestic currency lending by private banks to the nonfinancial sector, as detailed in Schularick \& Taylor (2012) and Jordà et al. (2013a). This measure includes loans to households and businesses. It excludes loans to government, interbank lending, and foreign currency lending, and it covers only the loan books of banks. All monetary institutions are covered, including savings banks, building societies, and some other bank-like entities. Securities in the trading book are not included, and any market-based credit or nonbank (shadow banking) credit is excluded as well. ${ }^{8}$ Significant efforts were needed to make the data as clean and consistent as possible and to track down obscure secondary and primary sources. Statistical concepts and definitions of banks and monetary institutions vary over time and space, and we relied on help from many scholars and organizations to assemble data for the first time in a coherent form. ${ }^{9}$

A major stylized fact to emerge from the data is shown in Figure 4. From 1870 to the present day, the advanced economies have at almost all times operated with ever-increasing levels of leverage, as measured by bank loans relative to GDP. The figure shows the simple average in each year, as well as the minimum-maximum and 1 standard deviation ranges. The only major exception to the tendency of rising leverage was the 1930-1950 period, when due to the Great Depression and World War II there was the near collapse of the financial systems in advanced economies, dramatic deleveraging, followed by slow recoveries, and then a shift to a planned war economy followed by an era of postwar financial repression. ${ }^{10}$ It took until 1970 for the average 1929 level of bank lending to GDP of $50 \%$ to be attained once more, but since 1970, this ratio has climbed to unprecedented levels, with the average breaching the $100 \%$ level for the first time on the eve of the 2008 global financial crisis.

Figure 5 confirms that the result is not driven by a peculiar subset of countries and shows the ratio of bank lending to GDP for each country at key selected 
Figure 4: The average ratio of bank lending to GDP in 17 advanced economies for each year since 1870 , as well as the minimum-maximum and 1 standard deviation (SD) ranges. Author's calculations are based on data from Jordà et al. (2013a).

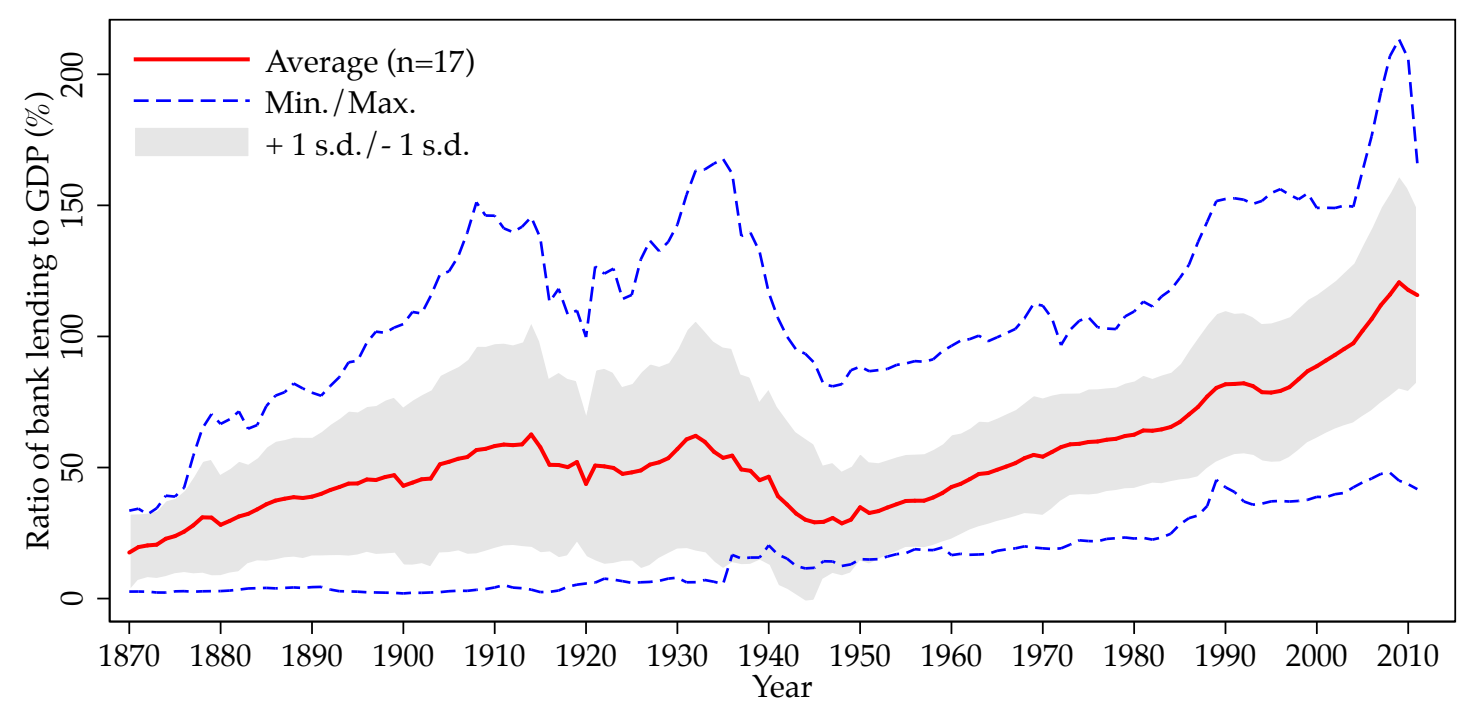

benchmark dates. The trend has not been driven by the United States, the AngloSaxons, or any specific country group. All countries have experienced a dramatic rise in their private credit ratio to GDP measured by our bank lending data, from 1870 to the present. In some cases, such as Australia, the Netherlands, and the United Kingdom, the change is most dramatic in the past few decades. In other cases, such as Denmark, Japan, Sweden, and Switzerland, the ratios were high early on but kept rising. In some countries, the banking system was almost nonexistent in 1870 but is very large today, such as Portugal and Spain. Other countries saw temporary declines in the ratio, such as Germany from 1900 to 1929, only to bounce back higher. Although the yearly averages in Figure 4 clearly conceal some country-specific variations in the path of credit expansion, the details in Figure 5 show that the long-run financialization trend toward a larger role for bank credit has been common to all advanced countries.

\subsection{Risk of Financial Crises}

As noted above, previous empirical work on the causes of crises, the early warning literature, focused on samples made up exclusively of, or heavily dominated by, 
Figure 5: The ratio of bank lending to GDP in 17 advanced economies for selected benchmark years since 1870. Author's calculations are based on data from Jordà et al. (2013a).
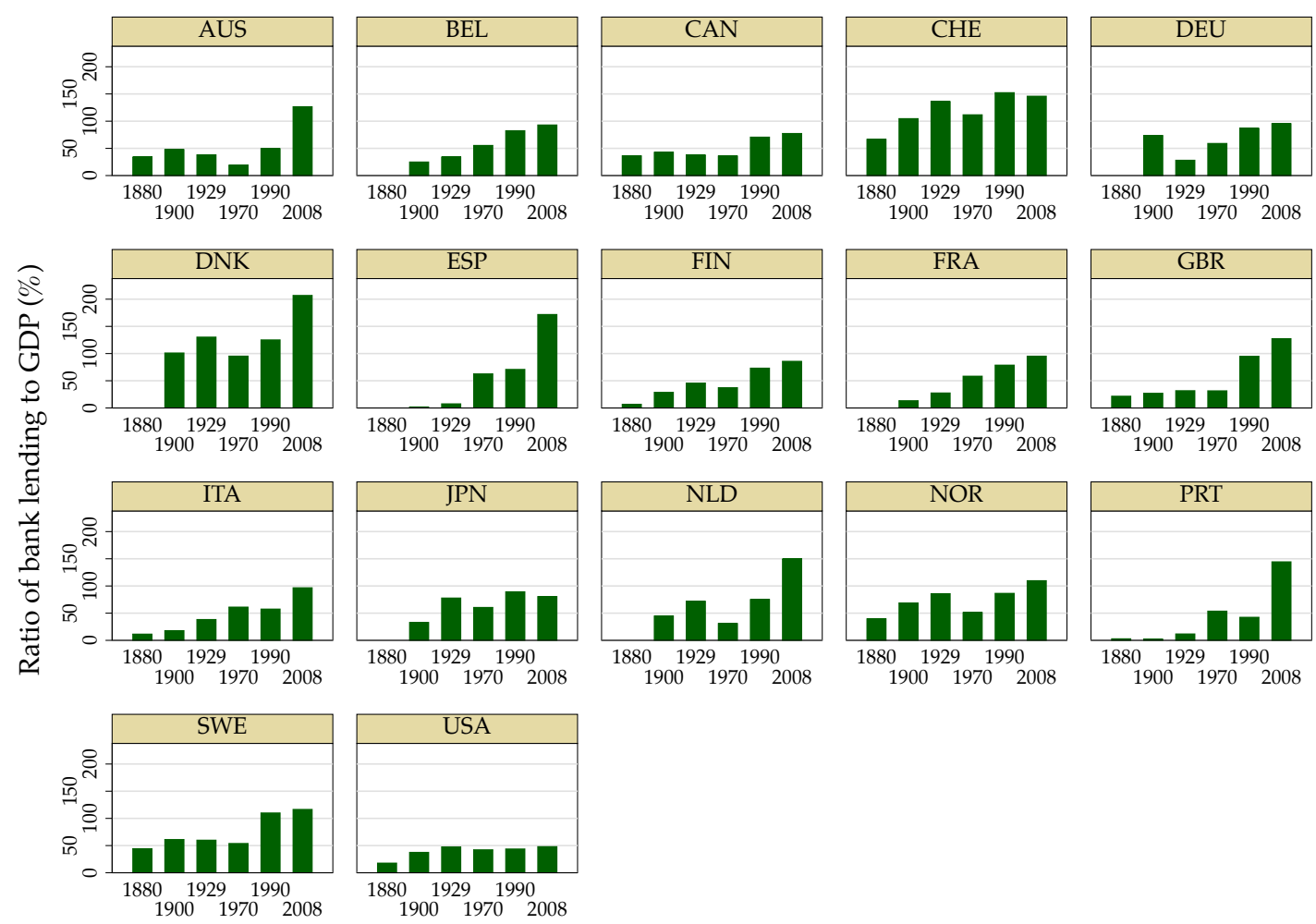

emerging economies. Possibly one reason for this, until 2008, was the relative infrequency of advanced-economy crises in the post-World War II sample of easily accessible data. But crises had happened somewhat regularly in emerging economies since the 1970s, which became the main area of concern. Studies found that multiple signals were informative of elevated crisis risk, but one consistently strong and reliable signal was credit, measured by either rapid recent growth or an unusually high level (or gap) relative to the trend, although the two measures end up being highly correlated, by construction (Kaminsky \& Reinhart 1999, Borio \& Lowe 2002a, Gourinchas \& Obstfeld 2012).

For a focus on the advanced economies, we need a longer historical sample, and much primary data collection work was required to make this possible. Indeed, with few exceptions (e.g., Eichengreen \& Mitchener 2003, focusing on the 1920s), the empirical investigation of credit-driven booms and busts in historical eras 
has been quite hampered by a lack of systematic data sets. With that challenge surmounted, the door is now open to deeper quantitative analysis. Our first task was then to assess and thus confirm the robustness of the credit signal as a forewarning signal of incipient financial crises in advanced countries. For this exercises, various papers (Schularick \& Taylor 2012, Jordà et al. 2013b) have used tools from the theory of binary classification and signal detection, principally the correct classification frontier (CCF) (Jordà \& Taylor 2011) as explained in Box 1.

We adapt these tools to explore the role of credit in predicting the onset of a financial crisis event, using the traditional crisis binary indicator noted above. ${ }^{11}$ Formally, in our panel data, suppose that a binary indicator CRISIS $S_{i t}$ takes the value 1 when a financial crisis happens in country $i$ at time $t$ and is o otherwise. A vector of macroeconomic variables $X_{t-1}$ known at time $t-1$ can be used as predictors of the crisis variable in an empirical probability model. Consider, for example, a standard fixed-effect logit model of the form

$$
\operatorname{logit}\left(p_{i t}\right)=\beta_{0 i}+\beta_{1}(L) C R E D I T_{i t}+\beta_{2}(L) X_{i t}+e_{i t}
$$

where $\operatorname{logit}(p)=\ln [p /(1-p)]$ is the $\log$ of the odds ratio for the CRISIS $S_{i t}=1$ event, $L$ is the lag operator, and fixed effects are included for each country in the panel. The CREDIT $T_{i t}$ variable is our measure of private credit, bank loans divided by GDP, and the lag polynomial $\beta_{1}(L)$ allows us to investigate whether the lags of credit are informative. The lag polynomial $\beta_{2}(L)$ allows for other possible causal factors in the form of an arbitrary set of additional macroeconomic control variables in the vector $X_{i t}$. We assume that the error term $e_{i t}$ is well behaved.

Table 1 and Figure 6 present CCF diagrams and estimation results based on logit models of the above (LOGIT) form, where for simplicity there are no additional controls $X$, and the lag polynomial in CREDIT takes the form of a five-year moving average of the change in total bank loans relative to GDP. The two world wars are excluded from the estimation sample. In all cases, the credit signal is seen to have predictive value at the $95 \%$ confidence level, where the test is based on the $A U C$ statistic, for which inference is relatively simple because the distribution is asymptotically normal. In the three cases, the AUC is 0.5 for the uninformative classifier, as shown by the diagonal reference line in the figure. In our case, we specify a null logit model with country fixed effects only and a 
Suppose that $d_{i t}$ is a binary outcome (o or 1 ), $\hat{\delta}_{i t}=\hat{\beta} X_{i t}$ is a parametric continuous (real) signal from a model (possibly estimated) that might predict the outcome based on observables $X$, and let $c$ (real) be some threshold value. A binary classifier is a prediction $\hat{d}_{i t}=I\left(\hat{\delta}_{i t}>c\right)$, where $I()$ is the indicator function. We define the sensitivity of the classifier as the true positive rate, $T P(c)=P\left(\hat{d}_{i t}=1 \mid d_{i t}=1\right)$, and the specificity of the classifier as the true negative rate $T N(c)=P\left(\hat{d}_{i t}=0 \mid d_{i t}=0\right)$.

We define the correct classification frontier, or $\mathrm{CCF}$, as the plot of the true positive rate $T P(c)$ against the true negative rate $T N(c)$, for all real thresholds $c$. If the threshold $c$ becomes large and negative, the classifier is very aggressive in making crisis calls, almost all signals are above the threshold, and $(T N, T P)$ converges to $(0,1)$ as $c \rightarrow-\infty$. Conversely, when $c$ becomes large and positive, the classifier is very conservative in making crisis calls, almost all signals are below the threshold, and $(T N, T P)$ converges to $(1,0)$ as $c \rightarrow+\infty$. In between these extremes, an informative classifier should deliver a CCF curve above the simplex or the $45^{\circ}$-line of the null uninformative (or coin toss) classifier, as shown in the figure below. The CCF is a variant of the better-known receiver operating characteristic curve.

The area under the CCF, known as the area under the curve $(A U C)$, is 0.5 for the null uninformative classifier and 1 for a perfect classifier. Concerning inference, testing whether a classifier is informative, or better than an alternative classifier, is simple with the AUC statistic because it is asymptotically normally distributed with a variance that can be easily estimated. The test is also independent of the operator's preferences. Such tests are available in most statistical packages, including STATA, which we have employed in our work.

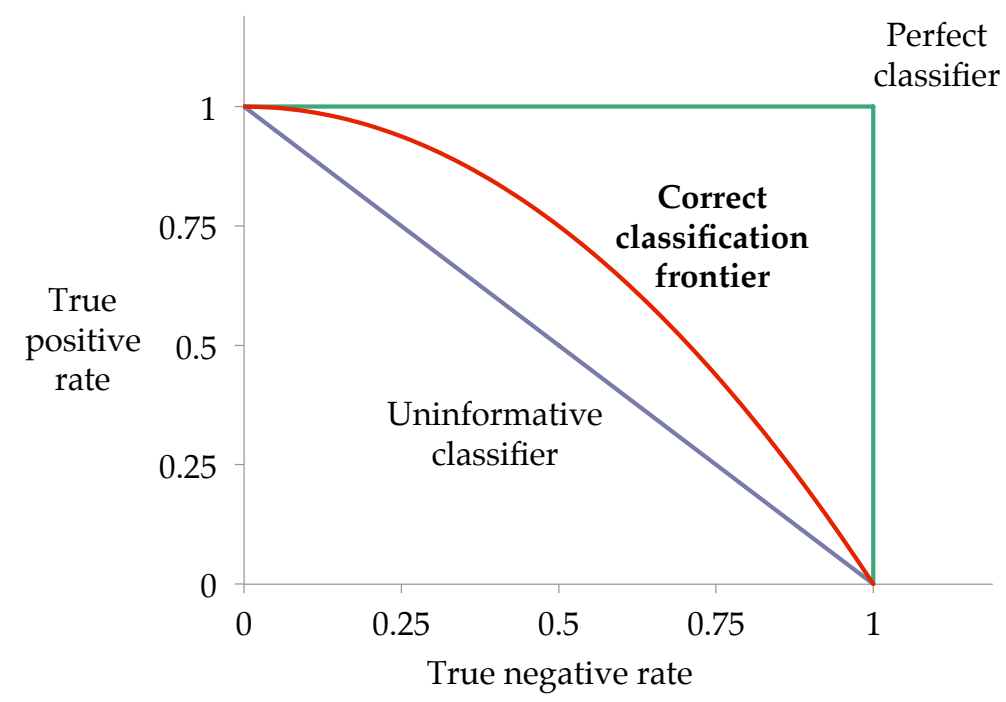

Box 1: BINARY CLASSIFICATION METHODS 
Table 1: Simple logit models of financial crises. The dependent variable is the CRISIS binary indicator of a financial crisis. The null model is a fixed-effect (FE) logit model with no regressors other than country intercepts. In all cases (full, pre-World War II, and post-World War II samples), the null is rejected, and the credit-based prediction model is found to be informative. The area under the curve (AUC) tests against the FE null. Standard errors are in parentheses. ${ }^{* *}$ for $p<0.05$ and ${ }^{* * *}$ for $p<0.01$. Author's calculations are based on data presented in Jordà et al. (2014).

\begin{tabular}{|c|c|c|c|c|c|c|}
\hline & \multicolumn{2}{|c|}{$\begin{array}{c}\text { Full } \\
\text { sample }\end{array}$} & \multicolumn{2}{|c|}{$\begin{array}{c}\text { Pre- } \\
\text { World War II } \\
\text { sample }\end{array}$} & \multicolumn{2}{|c|}{$\begin{array}{c}\text { Post- } \\
\text { World War II } \\
\text { sample }\end{array}$} \\
\hline & $\begin{array}{c}\text { FE } \\
\text { null }\end{array}$ & $\begin{array}{l}\mathrm{FE}+ \\
\text { credit }\end{array}$ & $\begin{array}{c}\text { FE } \\
\text { null }\end{array}$ & $\begin{array}{l}\text { FE + } \\
\text { credit }\end{array}$ & $\begin{array}{c}\text { FE } \\
\text { null }\end{array}$ & $\begin{array}{l}\text { FE + } \\
\text { credit }\end{array}$ \\
\hline Country FEs & Yes & Yes & Yes & Yes & Yes & Yes \\
\hline $\begin{array}{l}\text { Change in bank lending/GDP } \\
\text { (5-year lagged moving average) }\end{array}$ & & $\begin{array}{c}27.42^{* * *} \\
(5.13)\end{array}$ & & $\begin{array}{l}54 \cdot 30^{* * *} \\
(13 \cdot 74)\end{array}$ & & $\begin{array}{l}34.32^{* * *} \\
(8.77)\end{array}$ \\
\hline AUC & $\begin{array}{c}0.61 \\
(0.03)\end{array}$ & $\begin{array}{c}0.72^{* * *} \\
(0.03)\end{array}$ & $\begin{array}{l}0.63 \\
0.04)\end{array}$ & $\begin{array}{c}0.76^{* * *} \\
(0.04)\end{array}$ & $\begin{array}{c}0.62 \\
\text { (0.05) }\end{array}$ & $\begin{array}{l}0.75^{* *} \\
(0.05)\end{array}$ \\
\hline Number of observations & 2,040 & 1,818 & 1,003 & 790 & 976 & 967 \\
\hline
\end{tabular}

model with the credit variable. The CCFs for the latter are above the diagonal reference lines, and above the lines for the null fixed-effect models; each one has an $A U C$ well above 0.7 and significantly different from the respective null model's AUC.

In summary, for policy makers and researchers, the lesson of macroeconomic history is that we ignore credit at our peril. Credit booms often go wrong. Although no indicator can predict perfectly, credit aggregates contain predictive information about the likelihood of future financial crises. Sometimes credit expands normally to support real economic gains, but recurrent episodes of financial instability have more often than not been the result of abnormal credit expansion. If the costs of financial crises are judged too harsh, and policy makers seek indicators of when to use macroprudential tools to cool a dangerous boom, a simple credit indicator is a plausible candidate signal that is both useful and noncomplex, attributes that align well with the drift of recent policy proposals (Turner 2010, Drehmann 2013, Haldane \& Madouros 2013, Aikman et al. 2014). 
Figure 6: Correct classification frontiers for simple logit models of financial crises as a function of a five-year moving average of the change in total bank loans relative to GDP. The null model is an FE logit model with no regressors other than country intercepts. In all cases, the (a) full, (b) pre-World War II, and (c) post-World War II samples, the null is rejected, and the credit-based prediction model is found to be informative. Tests against the FE null are denoted ${ }^{* *}$ for $p<0.05$ and ${ }^{* * *}$ for $p<0.01$. Author's calculations are based on data from Jordà et al. (2014). Abbreviations: AUC, area under the curve; FE, fixed effect.
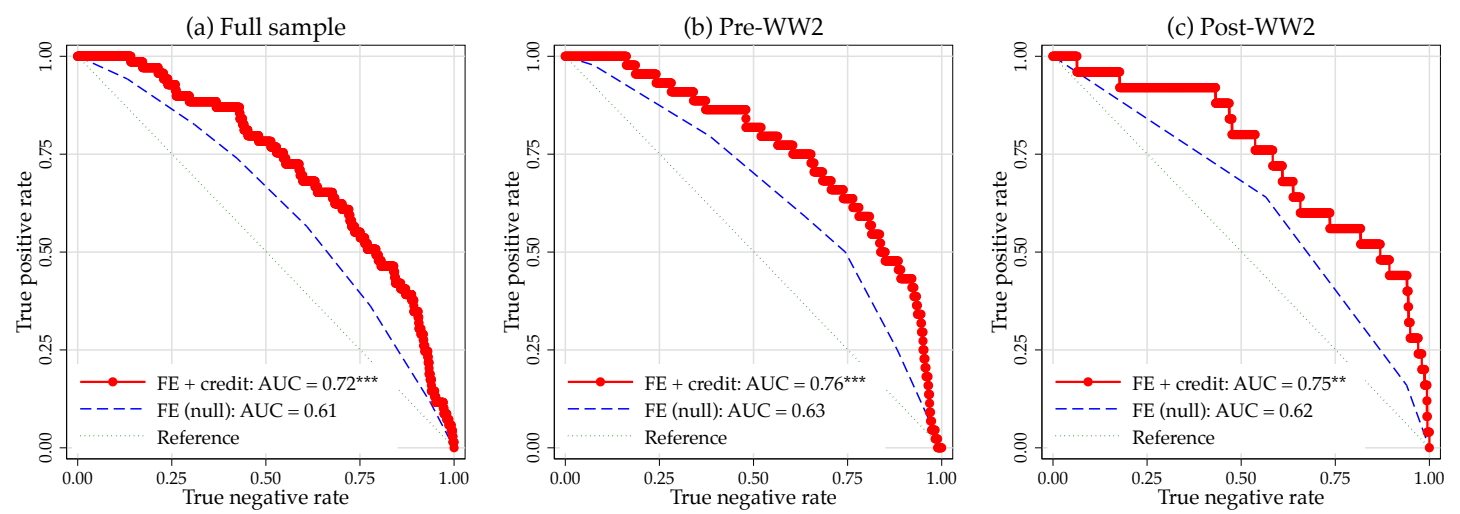

\subsection{Costs of Financial Crises}

The previous results sought to address one of the two main issues: What makes financial crises likely? The strong empirical correlation over 100 years in 17 advanced countries between a run-up in bank lending and the probability of a crisis event suggests that credit booms play a significant part in raising crisis risk. Without the careful historical work to construct the credit data, this kind of evidence has been hitherto unknowable.

Now we turn to the other main issue: What makes the recessions associated with financial crises so painful? Our research shows that the evolution of bank lending plays an important role here too, in that larger credit booms also cause the pace of economic recovery to significantly drag after recessions. These findings again make important use of our new and unique data set, and they resonate with very recent work highlighting how balance sheet effects shape recessions in both theory and practice (Koo 2009; Mian \& Sufi 2009, 2014; Eggertsson \& Krugman 2012; Mian et al. 2013), while connecting to the older economic traditions noted above (Fisher 1933, Kindleberger 1978, Minsky 1986). Still, further quantitative 
historical work can build on these results, some discussed below, and much of it lying in the future, so as to establish in more detail the channels through which these effects are felt.

But how can we establish the stylized facts? Look back for a moment to Figure 2, which shows that financial crisis recessions are far more painful than normal recessions, as measured by the depth of the downturn and the delay to the recovery path. Yet this evidence was simply taken from unconditional raw averages. To go further with formal empirical analysis, we can construct conditional responses, in which we control for the state of the economy entering the recession using a rich set of macroeconomic observables $X_{i t}$ to see whether the differences remain when other potentially important covariates enter the model.

Crucially, we want to include our bank lending measure CREDIT $T_{i t}$, in some way, to allow for the role of credit booms and busts in shaping the recovery path. To do this, Jordà et al. (2013a) construct a measure of excess credit, EXCESS ${ }_{\text {rit }}$, for each business-cycle expansion, defined as the change per year in bank loans relative to GDP (in percentage points per year) from trough to peak, as a proxy for the credit intensity of the boom phase, for recession type $r$ equal to $N$ or $F$, and relative to its mean for each type $r$.

We can then estimate a conditional path via LP, that is, a forward conditional path of log real GDP per capita or any other variable of interest (here denoted $y$ ), starting at the peak year of each expansion $t$, in country $i$, and running over future years at each annual horizon $h$ (Jordà 2005):

$$
\begin{aligned}
y_{i, t+h}-y_{i, t}= & a_{i h}+\theta_{N h} N_{i t}+\theta_{F h} F_{i t} \\
& +\beta_{N h} N_{t} E_{X C E S S_{N i t}}+\beta_{F h} F_{t} E_{X C E S S_{F i t}}+\Gamma_{h}(L) X_{i t}+u_{i t},
\end{aligned}
$$

where the LP approach provides an analog to a vector autoregression estimate of an impulse response, only with far more flexibility in form and far less parametric intensity.

In the above (LP) equation, the coefficients and estimate average conditional paths in normal and financial crisis recessions, respectively. (For comparison, the unconditional paths in Figure 2 would result from estimating the same LP equation but with no other controls, i.e., with the restrictions $\beta=\Gamma=0$.) The coefficients $\beta_{N h}$ and $\beta_{F h}$ estimate the average response in each type of recession 
to increments in the credit intensity of the expansion measured by our EXCESS $S_{\text {rit }}$ variable. Lastly, although not of interest here, the lag polynomial term coefficients $\Gamma_{h}(L)$ serve to capture the average response to changes in other macroeconomic state variables $X_{i t}$ that are observed in peak year $t$.

Based on data from Jordà et al. (2013a), Table 2 and Figure 7 report results of ordinary least squares fixed-effect panel estimates of the above (LP) equation with our new credit data set matched to a long-run macrohistorical data set of additional controls for the full sample. The conditioning variables added (with up to two lags) in $X_{i t}$ are: (a) the growth rate of real GDP per capita; (b) the growth rate of real loans per capita; (c) the CPI inflation rate; (d) short-term interest rates on government securities (usually three months or less in maturity); (e) long-term interest rates on government securities (usually five years or more in maturity); (f) the investment to GDP ratio; and (g) the current account to GDP ratio. ${ }^{12}$

Results are shown for six response variables of interest: real GDP per capita, real investment per capita, CPI price level, real private credit (bank loans) per capita, and short- and long-term interest rates. Compared to Figures 2 and 3, the sample size, now much reduced because of the requirement that data be available for all the conditioning variables, is 132 recessions (101 normal, 31 financial) in the full sample. Note that all of these paths are potentially different from those in the earlier figures because of both the presence of the conditioning variables and the resulting change in samples. For brevity, Table 2 reports only the estimates of the above (LP) equation for real GDP per capita. Similar to all the LPs, it allows for the coefficients on EXCESS to vary by recession type as above, although a test for equality shows that an equality restriction on the coefficients cannot be rejected: The drag from credit overhang is present in both financial crisis recessions and normal recessions.

There are two key takeaways here. First, our basic findings from the raw data, even when subject to the additional rigors of LP estimation with a large control set, are robust. In terms of output costs, financial crisis recessions are significantly longer and deeper than normal recessions, and in terms of other correlates, the differences are large, statistically significant, and of the expected direction. If there is a crisis, the recession is characterized by larger collapses in investment, a lower rate of price inflation, contractions rather than expansions of credit, lower interest rates, and a shift to current account surplus. All these differences can be 
Table 2: Local projection (LP) conditional paths of real GDP per capita in recessions. Shown is the LP conditional cumulative average path of real output per capita relative to the level in the peak year of the recession in both normal and financial crisis recessions in the advanced economies in the full sample. The dependent variable is (change in log real GDP per capita from year o to year $h$ ) 100 . Cluster-robust standard errors are in parentheses. ${ }^{*}, p<0.10 ;{ }^{* *}, p<0.05$. Country fixed effects are not shown. For the LM test, all excess credit coefficients equal zero: $F(10,585)=3.026 ; p=0.001$. In each crisis type bin, the recession indicators $(N, F)$ are interacted with demeaned excess credit $\left(E_{X X E S S_{N}}, E X C E S S_{F}\right)$. Author's calculations are based on data presented in Jordà et al. (2013a).

\begin{tabular}{|c|c|c|c|c|c|}
\hline $\begin{array}{l}\text { Log real GDP per capita } \\
\text { (relative to year } 0, \times 100 \text { ) }\end{array}$ & $\begin{array}{l}\text { Year } \\
h=1\end{array}$ & $\begin{array}{l}\text { Year } \\
h=2\end{array}$ & $\begin{array}{l}\text { Year } \\
h=3\end{array}$ & $\begin{array}{l}\text { Year } \\
h=4\end{array}$ & $\begin{array}{l}\text { Year } \\
h=5\end{array}$ \\
\hline Normal recession & $\begin{array}{l}-1.271^{* *} \\
(0.360)\end{array}$ & $\begin{array}{c}0.693 \\
(0.644)\end{array}$ & $\begin{array}{l}3.179^{* *} \\
(0.869)\end{array}$ & $\begin{array}{l}3.838^{* *} \\
(1.122)\end{array}$ & $\begin{array}{l}4.813^{* *} \\
(1.197)\end{array}$ \\
\hline Financial crisis recession & $\begin{array}{l}-2.828^{* *} \\
(0.574)\end{array}$ & $\begin{array}{l}-4.135^{* *} \\
(1.027)\end{array}$ & $\begin{array}{l}-3.586^{* *} \\
(1.386)\end{array}$ & $\begin{array}{l}-2.751 \\
(1.791)\end{array}$ & $\begin{array}{l}-1.365 \\
(1.910)\end{array}$ \\
\hline $\begin{array}{l}E^{E X C E S S_{N}} \text { (credit/GDP, demeaned) } \\
\quad \text { normal recession }\end{array}$ & $\begin{array}{l}-0.264 \\
(0.166)\end{array}$ & $\begin{array}{l}-0.684^{* *} \\
(0.297)\end{array}$ & $\begin{array}{l}-0.771^{*} \\
(0.401)\end{array}$ & $\begin{array}{l}-0.932^{*} \\
(0.518)\end{array}$ & $\begin{array}{l}-0.711 \\
(0.552)\end{array}$ \\
\hline $\begin{array}{l}E^{E X C E S S_{F}} \text { (credit/GDP, demeaned) } \\
\quad \text { financial crisis recession }\end{array}$ & $\begin{array}{l}-0.401^{*} \\
(0.213)\end{array}$ & $\begin{array}{l}-0.991^{* *} \\
(0.381)\end{array}$ & $\begin{array}{l}-0.374 \\
(0.515)\end{array}$ & $\begin{array}{l}-1.298^{*} \\
(0.665)\end{array}$ & $\begin{array}{l}-0.895 \\
(0.709)\end{array}$ \\
\hline $\begin{array}{l}F \text {-test equality of coefficients, } \\
\text { normal = financial }(p)\end{array}$ & 0.01 & 0.00 & 0.00 & 0.00 & 0.00 \\
\hline $\begin{array}{l}\text { F-test equality of coefficients, } \\
\text { interaction terms }(p)\end{array}$ & 0.57 & 0.47 & 0.49 & 0.62 & 0.82 \\
\hline Number of observations & 121 & 121 & 121 & 121 & 121 \\
\hline
\end{tabular}

seen, as before, by comparing the normal recession paths with the financial crisis recession paths in Figure 7, where all variables in the above (LP) equation are set to their sample average values (in particular, excess credit is set to zero).

The second key finding, however, concerns the way in which the prior credit boom affects the subsequent path of the economy. We evaluate this counterfactual in our LP model by a set of experiments that compare the above baseline paths with alternate paths that would be predicted to unfold when the level of excess credit is given a perturbation. Specifically, suppose that excess credit (the change per year in bank lending over GDP in the expansion phase) were set at a level +1 standard deviation above its mean; we then ask how the paths of the macroeconomic variables would be predicted to change, and again Figure 7 displays these counterfactuals for the case of normal recession and financial crisis recession 
Figure 7: The local projection, conditional cumulative average path of (a) real GDP per capita, (b) real investment per capita, (c) CPI price level, (d) real private credit (bank loans) per capita, (e) short-term interest rates, and ( $f$ ) long-term interest rates, all relative to the level in the peak year of the recession in both normal and financial crisis recessions in the advanced economies in the full sample. The solid lines show paths computed when excess credit is at its mean level, and the dotted lines show paths computed when excess credit is +1 standard deviation above its mean level. Figure reproduced from Jordà et al. (2013a). Abbreviations: CI, confidence interval; CPI, Consumer Price Index.

(a) Real GDP per capita

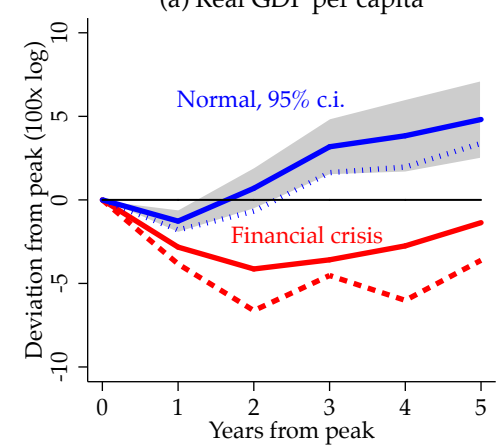

(d) Real Lending per capita

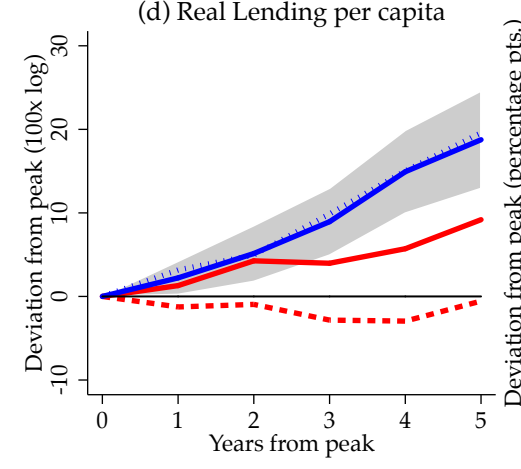

(b) Real Investment per capita

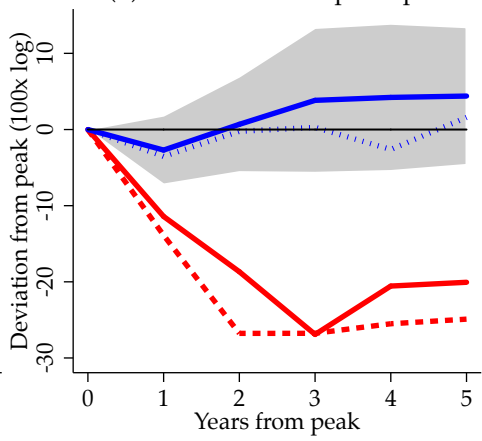

(e) Govt. Short-term Interest Rates

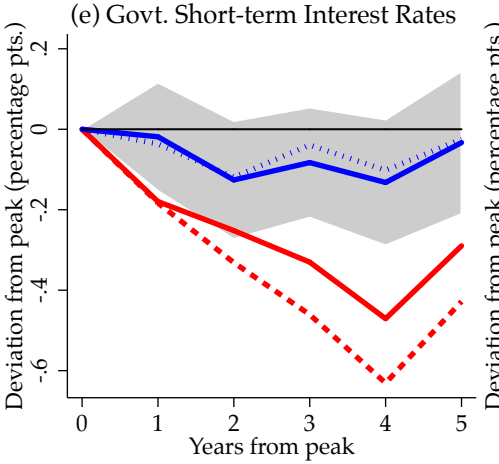

(c) CPI Prices

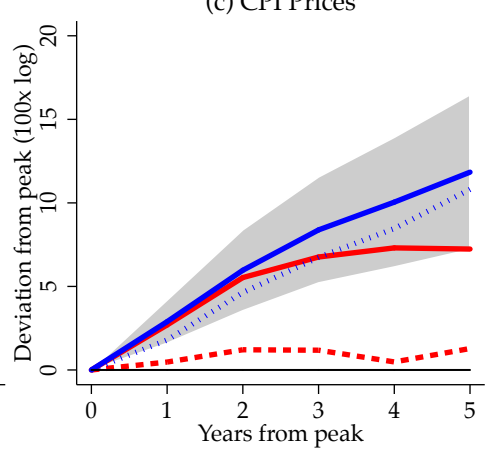

(f) Govt. Long-term Interest Rates

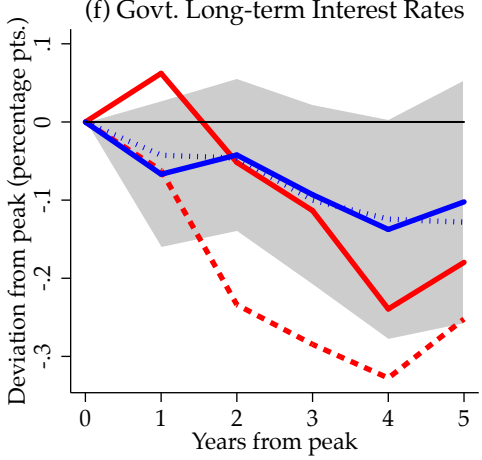

paths.

These paths help explain a second danger of credit booms; they not only make financial crises more likely, they are also associated with deeper and longer recessions. In Figure 7, the path of real GDP per capita is much more adverse when excess credit is perturbed +1 standard deviation. In the full sample, real GDP per capita is perturbed approximately $1.5 \%$ lower after five years in a normal recession and $3 \%$ lower in a financial crisis recession. In the latter case, the economy remains far below its previous peak. When the excess credit variable is elevated, we also see larger collapses in investment and sharper credit contractions. Thus, the bigger the credit boom, the bigger are the reversals in all these variables. By comparison, 
the effects on inflation and public debt are small and less significant.

In summary, we refer to this phenomenon as "credit bites back," and with the first result, it helps to unravel the mystery of why credit booms can lead to more painful recessions. For one thing, a credit boom makes a financial crisis more likely, and we clearly saw that financial crisis recessions are worse than normal recessions, on average. But even holding that effect constant, credit booms also lead to a debt overhang, which makes both types of recession more painful, conditional on whichever type of recession happens to take place.

\section{BANKS, SOVEREIGNS, FOREIGNERS, AND HOUSES}

The analysis above focuses on run-ups in the simple aggregate economy-wide credit-to-income gearing ratio, proxied by bank lending relative to GDP. This is a key predictor of both financial crisis fragility and the subsequent drag on economic growth after a recession begins. This has been true for more than a century, a period covering the entire duration of modern macroeconomic history under finance capitalism, in the advanced economies.

But how robust is this result to alternative empirical approaches that allow for other potential causes? Our research has focused on two potentially rival explanations. ${ }^{13}$ The first comes from those worried about the risks from global imbalances-according to this view, excessive external current account deficits could amplify or spillover into the risk of financial crises and recessions. The second comes from those worried about fiscal excess-according to that view, rising public sector debt levels could spillover into the risk of financial crises and recessions. However, neither of these hypotheses follows unambiguously from theory, so the question turns out to be an empirical one in each case.

\subsection{Risk of Financial Crises: Other Predictors}

To see whether these alternative predictors make a difference, Table 3 and Figure 8 show rival CCF results from logit models with a different auxiliary variable added. In Figure 8a, the added variable is the five-year lagged moving average of the change in the current account to GDP ratio, and in Figure 8a, the added variable is the five-year lagged moving average of the change in the public debt to GDP 
Table 3: Augmented logit models of financial crises with lagged credit growth plus current accounts or public debts. The dependent variable is the CRISIS binary indicator of a financial crisis. The null model is a fixed-effects (FE) logit model with no regressors other than country intercepts. The baseline credit model is compared to models with the current account and public debt. The area under the curve (AUC) tests against the FE null. Standard errors are in parentheses. $* * *, p<0.01$. Authors calculations are based on data presented in Jordà et al. $(2013 a, b)$.

\begin{tabular}{|c|c|c|c|c|}
\hline$\overline{\overline{\text { Full sample }}}$ & $\begin{array}{c}\text { FE } \\
\text { null }\end{array}$ & $\begin{array}{l}\mathrm{FE}+ \\
\text { credit }\end{array}$ & $\begin{array}{c}\text { FE + credit } \\
+ \text { current } \\
\text { account }\end{array}$ & $\begin{array}{c}\text { FE + credit } \\
+ \text { public } \\
\text { debt }\end{array}$ \\
\hline Country FEs & Yes & Yes & Yes & Yes \\
\hline $\begin{array}{l}\text { Change in bank lending/GDP } \\
\text { (5-year lagged moving average) }\end{array}$ & & $\begin{array}{c}27.42^{* * *} \\
(5.13)\end{array}$ & $\begin{array}{l}30.35^{* * *} \\
(5.68)\end{array}$ & $\begin{array}{c}26.77^{* * *} \\
(5.21)\end{array}$ \\
\hline $\begin{array}{l}\text { Change in Current account/GDP } \\
\text { (5-year lagged moving average) }\end{array}$ & & & $\begin{array}{l}-0.05 \\
(0.06)\end{array}$ & \\
\hline $\begin{array}{l}\text { Change in public debt/GDP } \\
\text { (5-year lagged moving average) }\end{array}$ & & & & $\begin{array}{l}-6.54 \\
(4.19)\end{array}$ \\
\hline$A U C$ & $\begin{array}{c}0.61 \\
(0.03)\end{array}$ & $\begin{array}{l}0.72^{* * *} \\
(0.03)\end{array}$ & $\begin{array}{l}0.73^{* * *} \\
(0.03)\end{array}$ & $\begin{array}{l}0.72^{* * *} \\
(0.03)\end{array}$ \\
\hline Number of observations & 2,040 & 1,818 & 1,768 & 1,723 \\
\hline
\end{tabular}

ratio. Each model can be run with credit, the auxiliary variable, both, or neither (the null being a simple country fixed-effect specification, again). Relative to the null or to the baseline model with the credit variable, these auxiliary variables do little to augment the predictive power of the logit crisis prediction model, as judged by the AUC statistics. Still, this result on crisis risk does not mean that public debt has no effects of interest in our analysis, and we consider public debt overhang and economic performance below.

For the current account, the raw data can provide some clarity as to why this is so. It turns out that credit booms and busts can be driven just as easily by domestic savings as by foreign savings. Following Taylor (2014), suppose we compute the correlations between external inflows (current account, percent of GDP) and the change in aggregate credit (change in bank loans, percent of GDP). If we divide the panel into 20-year periods from 1870 , excluding the two world wars, the answer is that over the long run the correlation of these two measures has been essentially zero. Only in one period, 1870-1889, was there a significant negative correlation between the current account and changes in bank lending. 
Figure 8: Correct classification frontiers for augmented logit models with lagged credit growth plus (a) current accounts or (b) public debts (see Figure 7). In panel a, CA uses a five-year lagged moving average of the change in the current account to GDP ratio. In panel b, "Pub. debt" uses a five-year lagged moving average of the change in the public debt to GDP ratio. Relative to either the "Null" or the "Credit" model, the addition of "CA" or "Pub. Debt" does not improve the classifier. Author's calculations are based on data from Jordà et al. $(2011,2013 b)$. Abbreviations: AUC, area under the curve; CA, current accounts; FE, fixed effect.

(a) Financial Crisis Risk and the Current Account

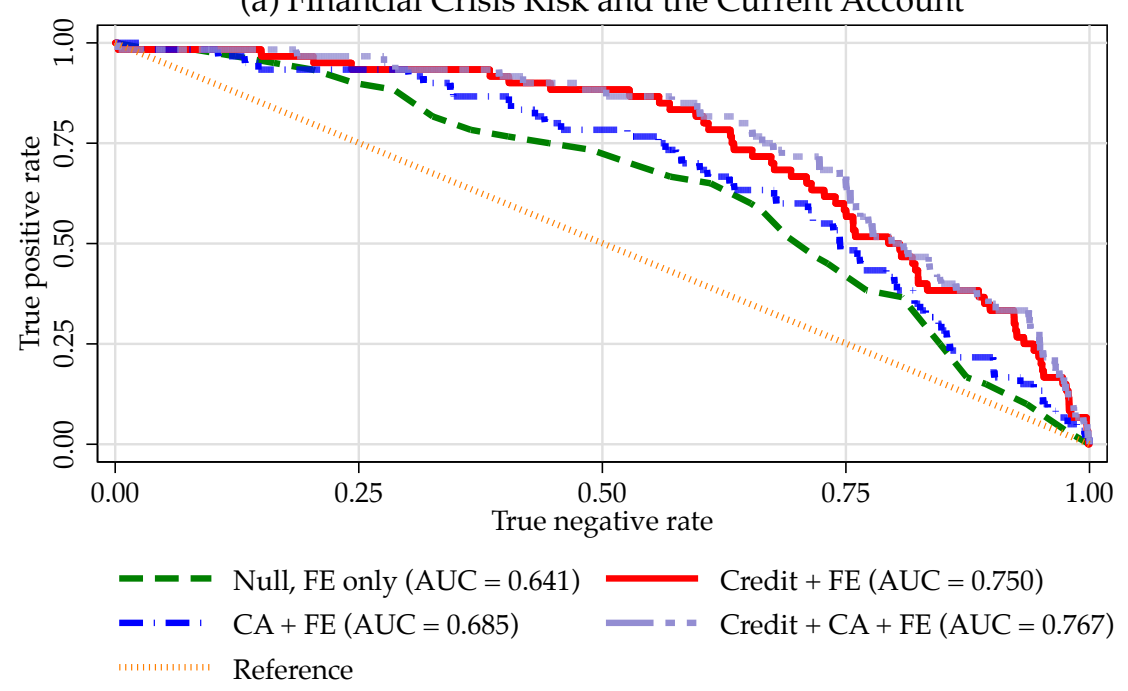

(b) Financial Crisis Risk and Public Debt

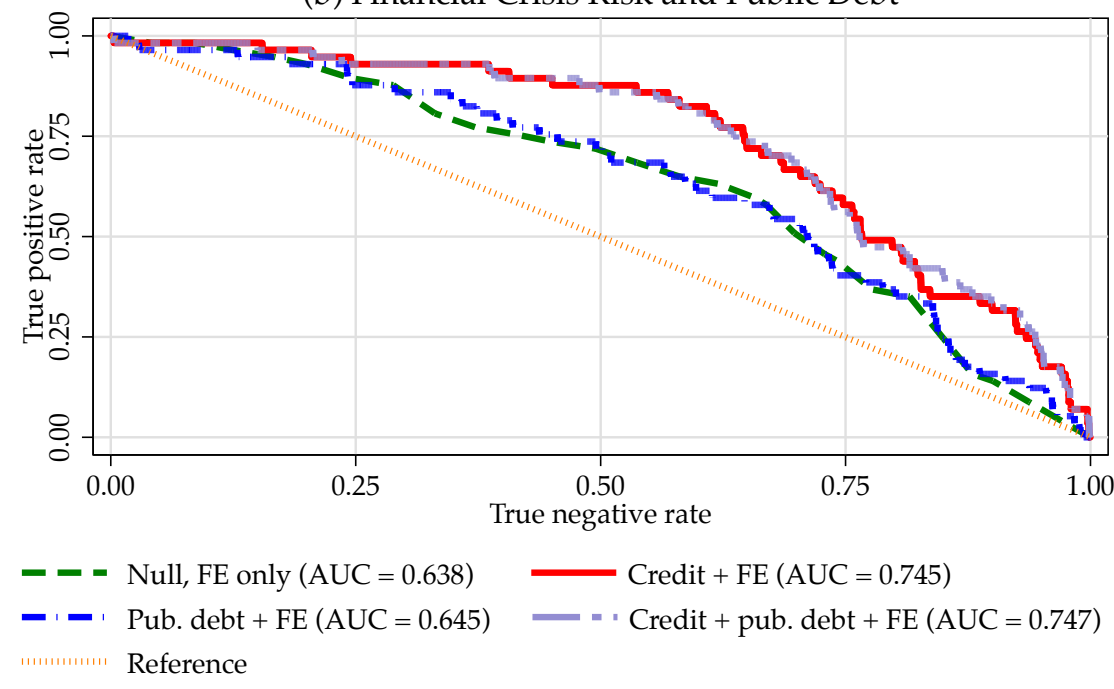


This is not surprising: It was a peak period of settler economy capitalism with large capital flows out of high-saving core economies. In one later period, the postwar years 1949-1968, there was a positive correlation: High-saving economies had current account surpluses but also rapidly expanding credit.

Over the course of history, current accounts have been imperfectly correlated with credit and hence perform poorly in a horse race to explain the probability of crises. In the nineteenth century, this was obvious: Britain was a surplus country for decades but had recurrent banking crises. Even in the 2008 global financial crisis, this was evident: Although many deficit countries suffered financial crises, banks also fell into distress in a number of surplus countries. Thus, although there may be cases in which large debt-driven capital inflows feed into a potentially dangerous domestic credit boom, the warning signs in the balance of payments will likely echo the credit signals in the domestic banking system, through which most of the funds will pass. In other cases, a domestic credit boom may have (and has) occurred without such inflows, so it is the bank credit indicator that is inevitably a more direct and reliable signal of domestic financial crisis risk.

Turning to the other candidate auxiliary variable, public debt, a similar logit model comparison adds the five-year lagged moving average change in public debt to GDP ratios as a crisis predictor, and the results are shown in Table 2 and Figure $8 \mathrm{~b}$. The public debt variable clearly has no benefit as a predictor even as compared to the country fixed-effect null. Thus, the idea that financial crises have their roots in fiscal problems is not supported over the long sweep of history. Some such cases may of course exist, like Greece today, but these have been the exception not the rule. In general, in countries such as Ireland and Spain today, financial crises can be traced back to original developments in the financial sector itself, namely excess credit, with fiscal problems emerging later as a symptom not a warning signal. However, as shown below, although public debt may not play a role in predicting a crisis event, it is not irrelevant in all respects. Public debt can play a significant role in shaping the paths of recessions and recoveries associated with financial crisis events.

In summary, over 140 years, there has been no systematic correlation of financial crisis risk with either prior current account deficits or prior growth in public debt levels. Private credit has always been the only useful and reliable predictive factor. 


\subsection{Costs of Financial Crises: Other Predictors}

The second question is whether the proposed auxiliary variables, external imbalances and rising public debt, even if they have no predictive power for financial crisis risk, still might influence the depth and duration of recessions as much as, or instead of, the effect we have identified as being driven by credit boom overhangs.

To investigate this question, we can estimate the LP models for the trajectory of the economy's real GDP per capita following a business-cycle peak, as above, but now with the proposed auxiliary variables added as additional conditioning information. Table 4 reports these LP results and a baseline model, in which the added covariate is the five-year lagged moving average of the current account or change in public debt. The baseline model in top part of the table is as before, but the coefficients on excess credit are uniform across recession types (that restriction could not be rejected in Table 2).

The results show that our earlier baseline findings in Table 2 are robust. First, the results in Table 4 with the addition of the current account variable are weak. The coefficient is possibly of the expected positive sign, in that a larger prior capital inflow bonanza (i.e., a negative current account) would predict the likelihood of a worse recession, but the statistical significance does not rise to even the $90 \%$ confidence level at any horizon. Most importantly, the magnitude and statistical significance of the effect of the prior credit boom are unaltered by the inclusion of this variable.

Similarly, the results in Table 4 for the addition of the public debt variable are not significant. Rising public debt in and of itself does not exacerbate the pain suffered in a recession, in this simplest formulation. It is systematically only high private credit that poses the greater threat to economic recovery, in the form of an overhang of leverage in the private household and business sectors.

Even so, in the most recent work from our ongoing project, some further refinements to these results have taken on importance. We have found that public debt, under some circumstances, can pose a threat to the economic recovery, and not all forms of private credit are equally dangerous. These results follow from empirical investigations using more general logit and LP specifications to evaluate the complex nexus of financial risks. 
Table 4: Alternative local projection (LP) conditional paths of real GDP per capita in recessions. Shown is the LP conditional path of real output per capita relative to the level in the peak year of the recession in both normal and financial crisis recessions in the advanced economies in the full sample. Cluster-robust standard errors errors are in parentheses. $*, p<0.1 ; * *, p<0.05 ; * * *, p<0.01$. Authors calculations are based on data presented in Jordà et al. (2013a). Abbreviation: m.a., moving average.

\begin{tabular}{lcccccc}
\hline \hline Log real GDP per capita & Year & Year & Year & Year & Year & \\
(relative to year o, $\times 100)$ & $h=1$ & $h=2$ & $h=3$ & $h=4$ & $h=5$ & Sum \\
\hline (a) Baseline model, excess credit only & & & & & \\
\hline Normal recession & $-1.67^{* * *}$ & 0.32 & $2.07^{* * *}$ & $3.54^{* * *}$ & $5.04^{* * *}$ & $9.29^{* * *}$ \\
& $(0.16)$ & $(0.35)$ & $(0.38)$ & $(0.44)$ & $(0.45)$ & $(1.54)$ \\
Financial crisis recession & $-3.14^{* * *}$ & $-4.33^{* * *}$ & $-3.21^{* *}$ & -1.96 & 0.12 & $-12.51^{* * *}$ \\
& $(0.56)$ & $(1.03)$ & $(1.11)$ & $(1.24)$ & $(1.17)$ & $(4.09)$ \\
EXCESS, of credit/GDP & -0.21 & -0.42 & $-0.54^{*}$ & $-0.93^{* *}$ & $-1.09^{* *}$ & $-3.19^{*}$ \\
$\quad$ 5-year lagged moving avg.) & $(0.22)$ & $(0.43)$ & $(0.29)$ & $(0.42)$ & $(0.44)$ & $(1.67)$ \\
$R^{2}$ & 0.62 & 0.38 & 0.44 & 0.39 & 0.51 & 0.41 \\
Number of observations & 145 & 145 & 145 & 145 & 145 & 145 \\
\hline (b) Baseline model, plus current account & & & & & \\
\hline Normal recession & $-1.60^{* * *}$ & 0.37 & $2.15^{* * *}$ & $3.64^{* * *}$ & $5.16^{* * *}$ & $9.72^{* * *}$ \\
& $(0.19)$ & $(0.44)$ & $(0.44)$ & $(0.47)$ & $(0.47)$ & $(1.86)$ \\
Financial crisis recession & $-2.97^{* * *}$ & $-4.20^{* * *}$ & $-3.12^{* *}$ & -2.40 & -0.23 & $-12.91^{* *}$ \\
& $(0.60)$ & $(1.13)$ & $(1.18)$ & $(1.38)$ & $(1.42)$ & $(4.46)$ \\
EXCESS, of credit/GDP & -0.23 & -0.45 & $-0.57^{* *}$ & $-0.94^{* *}$ & $-1.01^{* *}$ & $-3.19^{* *}$ \\
$\quad$ 5-year lagged moving avg.) & $(0.20)$ & $(0.41)$ & $(0.24)$ & $(0.38)$ & $(0.40)$ & $(1.48)$ \\
Current account/GDP & 0.16 & 0.20 & 0.28 & 0.38 & 0.52 & 1.53 \\
$\quad$ 5-year lagged moving avg.) & $(0.11)$ & $(0.17)$ & $(0.24)$ & $(0.33)$ & $(0.41)$ & $(1.21)$ \\
$R^{2}$ & 0.64 & 0.39 & 0.47 & 0.43 & 0.54 & 0.45 \\
Number of observations & 139 & 139 & 139 & 139 & 139 & 139 \\
\hline (c) Baseline model, plus change in public debt & & & & \\
\hline Normal recession & $-1.56^{* * *}$ & 0.25 & $2.09^{* * *}$ & $3.67^{* * *}$ & $5.35^{* * *}$ & $9.80^{* * *}$ \\
Number of observations & $(0.12)$ & $(0.37)$ & $(0.39)$ & $(0.43)$ & $(0.45)$ & $(1.61)$ \\
Financial crisis recession & $-2.26^{* * *}$ & $-3.32^{* *}$ & $-2.51^{*}$ & -2.17 & -0.26 & $-10.52^{*}$ \\
EXCESS, of credit /GDP & $(0.70)$ & $(1.17)$ & $(1.27)$ & $(1.43)$ & $(1.34)$ & $(4.98)$ \\
(5-year lagged moving avg.) & -0.01 & -0.06 & $-0.41^{* *}$ & $-0.75^{* *}$ & $-0.86^{*}$ & $-2.10^{* *}$ \\
\hline \hline
\end{tabular}




\subsection{The Role of Public Debt}

The first finding worth noting here presents a caveat to the result that public debt is not an important factor in financial crises. Jordà et al. (2013b) find the above result that the level of public credit does not affect the recession and recovery path when it enters the LP specification linearly but do find a strong and significant effect when it enters nonlinearly and is interacted with the growth of private credit, especially in the case of financial crisis recessions. According to this result, when rapid run-ups occur in private credit, a high level of public debt may create the risk of slow recovery.

The result provides support for the argument that governments might need to retain fiscal space if they want to be better able to take lender-of-last-resort and/or countercyclical policy measures (i.e., financial sector support, fiscal stimulus, measures to offset private deleveraging) in the event that a highly leveraged financial crisis recession should occur. This would be a good example of what Obstfeld (2013) refers to as policy makers "keeping the powder dry." The eurozone crisis

experiences in Ireland and Spain are only the latest example of countries lacking policy space (given the rules of the euro) and being left with few macroeconomic tools as a deep depression takes shape; yet, as our research shows, this is a pattern that holds more generally across the broad sweep of history.

\subsection{The Role of Mortgages}

The other result to mention concerns whether different types of private credit pose greater or lesser danger of financial crisis risk or the risk of a more painful recession event. To study this question, we have returned to collect more data and examine disaggregated measures of bank credit in our sample. In new work, Jordà et al. (2014, 2015a) make a second pass and revisit all of their primary and secondary sources, and many new documents, to construct detailed disaggregated credit data for each country's banking system back to 1870 , with the most crucial decomposition turning out to be the difference between mortgage and nonmortgage credit, that is, loans secured by real estate versus typical business loans for industrial and commercial purposes.

Revisiting the analysis described above, we find convincing evidence that the 
financial systems in advanced countries, and the risks they generate, have shifted considerably in the past 100 years, a change we refer to as "the great mortgaging." The share of mortgages on bank balance sheets was one-third a century ago but is two-thirds in recent years, reflecting a reorientation of the banks' business models away from the classic textbook loanable funds view of banks intermediating between household savers and business investors and toward a different model in which banks largely provide housing finance for buyers of mostly existing real estate.

Alongside this shift, mortgage credit growth has become a more dominant driver of financial crisis risk, and mortgage credit overhang now weighs more on economic performance in recessions. In contrast, in recent times, nonmortgage lending creates lower risks and less drag. To be sure, mortgage lending does not appear to be a macroprudential risk at all times and in all places. These patterns hold in the post-World War II era, but they were absent before that time; this could lead to speculation that changes in policies, institutions, or other trends after 1945 have taken the advanced economies in a new direction, with greater housing leverage posing a new threat to macroeconomic stability. Such topics undoubtedly cry out for future research.

\subsection{Other Predictors and Directions for Future Research}

Subject to data availability constraints, there are of course many other potential indicators that could be explored in our historical data context as having possible additional influences on either the risk of crisis or the costs of financial crisis recessions. For example, Schularick \& Taylor (2012) find that although credit growth is a good predictor of crises, broad money is a less robust predictor (especially in the post-World War II era), and narrow money is entirely useless as a predictor of financial crises. This argues for policy makers to focus less on central bank balance sheets, or even broad money, and more on board credit aggregates when evaluating crisis risk. An important set of potential indicators includes asset prices, in particular equity and housing price movements. In some very influential work, Borio \& Lowe (2002b), followed up by Borio \& Drehmann (2009), find that rapid credit growth combined with increases in asset prices raise the probability of an episode of financial instability in a contemporary data set 
of 34 advanced and emerging economies from 1960 to 1999. In our next stage of work, in progress, we have compiled long-run data on equity and housing prices since 1870 for 14 advanced economies, and we find some evidence that asset price signals, combined with credit growth, might have played an influential role in the very much longer run in predicting crises and worsening recessions (Jordà et al. 2015b). In particular, we find as a regular feature of history that leveraged bubbles are particularly dangerous, especially so when they are in the form of synchronous house price and mortgage credit booms. In this sense, the crisis of 2008 was less of a black swan event, and more of an acute recurrence of a chronic condition.

\section{CONCLUSION}

The 2008 global financial crisis and Great Recession have placed the issues of credit and financial stability back at the center of academic research, which is where they were when the field of macroeconomics began. They have pushed the same issues back onto the list of key policy-making responsibilities that modern central banks must accept as part of their remit, which is also where they were when modern central banks began.

The challenge now is no less than that after the last great test of academic research and policy making in the Great Depression, and a pessimist might conclude that we have made very little progress in the meantime. At least in this article, I hope to have shown that empirical macroeconomic science, backed by far-superior historical data and more advanced statistical methods, is now much better placed to evaluate the evidence, theories, policy problems, and trade-offs than our predecessors 80 years ago.

Credit and financial stability are intimately linked, with potentially grave consequences for macroeconomic performance. Ignoring these connections risks exposing the world to many more crises like the one just experienced. The same would have been said in the 1930s. An economist time traveler from that earlier era would alight today in an all too familiar landscape and might wonder what had happened in the meantime and if we had actually learned anything along the way. Witness the sentiments of the Macmillan Committee (1931, p. 131) in their closing words on the international problems of credit and monetary policies 
facing central banks, which deserve to be quoted at length:

Yet a Central Bank, if it attempts to curb an upward movement, may and will be criticised for cutting short the country's nascent prosperity. Even when the recent American boom had grown to very great proportions, there was strenuous and widespread opposition in every quarter, even the most authoritative, to any attempt seriously to control it. To the difficulties of the control by a Central Bank of its own market must be added the additional difficulty of securing concerted action by several. Even if it were conceded that such concerted action would generally be effective if it were taken soon enough, it may be argued that it is not in fact practicable to detect and interpret the obscure premonitory signs of the financial weather soon enough or accurately enough, or with a high enough degree of probability, to procure concerted action amongst a number of independent authorities, each of which is likely to have its own ideas based on its local information and to maintain them with tenacity. Here again only time can show. There is no need to minimise the difficulty of the high enterprise which we should like to see the Central Banks of the world put in hand.

It is possible, indeed, to prescribe the objective of Central Bank policy. It is possible to suggest ways of increasing the means at the disposal of the Central Banks. But the use made of their discretionary power to vary the value of currency and credit, and the terms on which the latter is granted, must depend on experience and the daily exercise of prescience and a wide discretion. Any great measure of success, indeed, will only be reached as a result of a long process of experiment and evolution. At present, any deliberate effort at stability, however crude in its methods and partial in its success, would be a great improvement. It is sufficient for the time, therefore, to indicate the direction and objective of progress. 


\section{APPENDIX A: SYSTEMIC FINANCIAL CRISES}

The crisis prediction classification models in the article employ data on all systemic financial crises from 1870 to 2011. Dates of systemic financial crises provided in Appendix Table 1 are based on Jordà et al. (2011) and Schularick \& Taylor (2012), sources therein, and updates.

Appendix Table 1. Dates of systemic financial crises, 1870-2011.

\begin{tabular}{ll}
\hline \hline Country & Years of systemic financial crises \\
\hline Australia & 1893,1989 \\
Belgium & $1870,1885,1925,1931,1939,2008$ \\
Canada & $1873,1907,1923$ \\
Denmark & $1877,1885,1908,1921,1987,2008$ \\
Finland & $1878,1900,1921,1931,1991$ \\
France & $1882,1889,1930,2008$ \\
Germany & $1873,1891,1901,1907,1931,2008$ \\
Italy & $1873,1887,1893,1907,1921,1930,1935,1990,2008$ \\
Japan & $1882,1900,1904,1907,1913,1927,1997$ \\
Netherlands & $1893,1907,1921,1939,2008$ \\
Norway & $1899,1922,1931,1988$ \\
Portugal & $1890,1920,1923,1931,2008$ \\
Spain & $1883,1890,1913,1920,1924,1931,1978,2008$ \\
Sweden & $1878,1907,1922,1931,1991,2008$ \\
Switzerland & $1870,1910,1931,1991,2008$ \\
United Kingdom & $1873,1890,1974,1984,1991,2007$ \\
United States & $1873,1884,1893,1907,1929,1984,2007$ \\
\hline \hline
\end{tabular}

\section{APPENDIX B: NORMAL AND FINANCIAL CRISIS RECESSIONS}

The LP analysis in the article employs business-cycle peaks from 1870 to 2006, excludes windows around the two world wars, reports projections out to five years ahead, and uses the annual panel sample data for which the last year's projections from 2006 end in 2011. As a result, peaks from the 2007-2011 period are not used in the sample, meaning that the empirical work does not include the global financial crisis as an in-sample event. The peak dates used are shown in Appendix Table 2. The peak-trough dating method follows Jordà et al. (2011) and uses the Bry \& Boschan (1971) algorithm. 
Appendix Table 2. Dates of normal and financial crisis recession peaks, 1870-2006.

\begin{tabular}{|c|c|c|}
\hline Country & Recession type $^{a}$ & Years when recessions start (business-cycle peaks) \\
\hline \multirow[t]{2}{*}{ Australia } & Normal & $\begin{array}{l}1875,1878,1881,1883,1885,1887,1889,1896,1898, \\
1900,1904,1910,1913,1926,1938,1943,1951,1956, \\
1961,1973,1976,1981\end{array}$ \\
\hline & Financial crisis & $1891,1894,1989$ \\
\hline \multirow[t]{2}{*}{ Belgium } & Normal & $\begin{array}{l}1872,1874,1887,1890,1900,1913,1916,1942,1951, \\
1957,1974,1980,1992\end{array}$ \\
\hline & Financial crisis & $1870,1883,1926,1930,1937$ \\
\hline \multirow[t]{2}{*}{ Canada } & Normal & $\begin{array}{l}1871,1877,1882,1884,1888,1891,1894,1903,1913, \\
1917,1928,1944,1947,1953,1956,1981,1989\end{array}$ \\
\hline & Financial crisis & 1874,1907 \\
\hline \multirow[t]{2}{*}{ Denmark } & Normal & $\begin{array}{l}\text { 1870, 1880, 1887, 1911, 1914, 1916, 1923, 1939, 1944, } \\
1950,1962,1973,1979,1992\end{array}$ \\
\hline & Financial crisis & $1872,1876,1883,1920,1931,1987$ \\
\hline Finland & Financial crisis & $\begin{array}{l}1870,1883,1890,1898,1907,1913,1916,1938,1941, \\
1943,1952,1957,1975 \\
1876,1900,1929,1989\end{array}$ \\
\hline \multirow[t]{2}{*}{ France } & Normal & $\begin{array}{l}1872,1874,1892,1894,1896,1900,1905,1907,1909, \\
1912,1916,1920,1926,1933,1937,1939,1942,1974, \\
1992\end{array}$ \\
\hline & Financial crisis & 1882,1929 \\
\hline \multirow[t]{2}{*}{ Germany } & Normal & $\begin{array}{l}\text { 1879, 1898, 1905, 1913, 1922, 1943, 1966, 1974, 1980, } \\
\text { 1992, } 2001\end{array}$ \\
\hline & Financial crisis & $1875,1890,1908,1928$ \\
\hline \multirow[t]{2}{*}{ Italy } & Normal & $\begin{array}{l}\text { 1870, 1883, 1897, 1918, 1923, 1925, 1932, 1939, 1974, } \\
\text { 2002, } 2004\end{array}$ \\
\hline & Financial crisis & $1874,1887,1891,1929,1992$ \\
\hline \multirow[t]{2}{*}{ Japan } & Normal & $\begin{array}{l}\text { 1875, 1877, 1880, 1887, 1890, 1892, 1895, 1898, 1903, } \\
1919,1921,1929,1933,1940,1973,2001\end{array}$ \\
\hline & Financial crisis & 1882, 1901, 1907, 1913, 1925, 1997 \\
\hline \multirow[t]{2}{*}{ Netherlands } & Normal & $\begin{array}{l}1870,1873,1877,1889,1894,1899,1902,1913,1929, \\
1957,1974,1980,2001\end{array}$ \\
\hline & Financial crisis & 1892, 1906, 1937, 1939 \\
\hline \multirow[t]{2}{*}{ Norway } & Normal & $\begin{array}{l}1876,1881,1885,1893,1902,1916,1923,1939,1941, \\
1957,1981\end{array}$ \\
\hline & Financial crisis & $1897,1920,1930,1987$ \\
\hline \multirow[t]{2}{*}{ Portugal } & Normal & $\begin{array}{l}\text { 1870, 1873, 1877, 1888, 1893, 1900, 1904, 1907, 1912, } \\
1914,1916,1925,1927,1934,1937,1939,1941,1944, \\
1947,1951,1973,1982,1992,2002,2004\end{array}$ \\
\hline & Financial crisis & $1890,1923,1929$ \\
\hline \multirow[t]{2}{*}{ Spain } & Normal & $\begin{array}{l}1873,1877,1892,1894,1901,1909,1911,1916,1927, \\
1932,1935,1940,1944,1947,1952,1958,1974,1980, \\
1992\end{array}$ \\
\hline & Financial crisis & $1883,1889,1913,1925,1929,1978$ \\
\hline
\end{tabular}




\section{Appendix Table 2. Ctd.}

\begin{tabular}{|c|c|c|}
\hline$\overline{\text { Country }}$ & Recession type $^{a}$ & Years when recessions start (business-cycle peaks) \\
\hline \multirow[t]{2}{*}{ Sweden } & Normal & $\begin{array}{l}1873,1876,1881,1883,1885,1888,1890,1899,1901, \\
1904,1913,1916,1924,1939,1976,1980\end{array}$ \\
\hline & Financial crisis & $1879,1907,1920,1930,1990$ \\
\hline \multirow[t]{2}{*}{ Switzerland } & Normal & $\begin{array}{l}\text { 1875, 1880, 1886, 1890, 1893, 1899, 1902, 1906, 1912, } \\
1916,1920,1933,1939,1947,1951,1957,1974,1981, \\
1994,2001\end{array}$ \\
\hline & Financial crisis & $1871,1929,1990$ \\
\hline \multirow[t]{2}{*}{ United Kingdom } & Normal & $\begin{array}{l}1871,1875,1877,1883,1896,1899,1902,1907,1918, \\
1925,1929,1938,1943,1951,1957,1979\end{array}$ \\
\hline & Financial crisis & $1873,1889,1973,1990$ \\
\hline \multirow[t]{2}{*}{ United States } & Normal & $\begin{array}{l}\text { 1875, 1887, 1889, 1895, 1901, 1909, 1913, 1916, 1918, } \\
1926,1937,1944,1948,1953,1957,1969,1973,1979, \\
1981,1990,2000\end{array}$ \\
\hline & Financial crisis & $1873,1882,1892,1906,1929$ \\
\hline
\end{tabular}

$\overline{\bar{a} \text { Normal denotes a normal business-cycle peak, and Financial crisis denotes a peak associated }}$ with a systemic financial crisis, that is, a crisis within \pm 2 years of the peak. 


\section{LITERATURE CITED}

Acemoglu D, Johnson S, Robinson J, Thaicharoen Y. 2003. Institutional causes, macroeconomic symptoms: volatility, crises and growth. J. Monet. Econ. 50:49-123

Aikman D, Haldane AG, Nelson BD. 2015. Curbing the credit cycle. Econ. J. In press. doi: 10.1111/ecoj.12113

Attwood T. 1817. Prosperity Restored, or, Reflections on the Cause of the Public Distresses and on the Only Means of Relieving Them. London: Baldwin, Cradock, and Joy/Longman Hurst \& Co.

Bagehot W. 1873. Lombard Street: A Description of the Money Market. London: Henry S. King

Bernanke B. 1981. Bankruptcy, liquidity, and recession. Am. Econ. Rev. 71:155-59

Bernanke B. 1983. Nonmonetary effects of the financial crisis in the propagation of the Great Depression. Am. Econ. Rev. 73:257-76

Bernanke B, Gertler M. 1989. Agency costs, net worth, and business fluctuations. Am. Econ. Rev. 79:14-31

Bernanke B, Gertler M, Gilchrist S. 1996. The financial accelerator and the flight to quality. Rev. Econ. Stat. 78:1-15

Bordo MD, Eichengreen B, Klingebiel D, Martinez-Peria MS. 2001. Is the crisis problem growing more severe? Econ. Policy 32:51-75

Borio C, Drehmann M. 2009. Assessing the risk of banking crises-revisited. BIS Q. Rev. 2009(1):29-46

Borio C, Lowe P. 2002a. Assessing the risk of banking crises. BIS Q. Rev. 2002(4):43-54

Borio C, Lowe P. 2002b. Asset prices, financial and monetary stability: exploring the nexus. Work. Pap. 114, Bank Int. Settl., Basel, Switz.

Borio C, White WR. 2004. Whither monetary and financial stability? The implications of evolving policy regimes. In Monetary Policy and Uncertainty: Adapting to a Changing Economy; Proc. Symp. Spons. Fed. Reserve Bank Kansas City, pp. 131-211. Kansas City, MO: Fed. Reserve Bank Kansas City

Bry G, Boschan C. 1971. Cyclical Analysis of Time Series: Selected Procedures and Computer Programs. Cambridge, MA: NBER

Capie F. 2010. The Bank of England: 1950s to 1979. Cambridge, UK: Cambridge Univ. Press

Caprio G, Klingebiel D. 1996. Bank insolvencies: cross country experience. Work. Pap. 1620, World Bank, Washington, DC

Caprio G, Klingebiel D. 2002. Episodes of systematic and borderline financial crises. In Managing the Real and Fiscal Effects of Banking Crises, ed. D Klingebiel, L Laeven, pp. 31-49. Washington, DC: World Bank

Cerra V, Saxena SC. 2008. Growth dynamics: the myth of economic recovery. Am. Econ. Rev. 98:439-57

Drehmann M. 2013. Total credit as an early warning indicator for systemic banking crises. BIS Q. Rev. 2013(2):41-45 
Eggertsson GB, Krugman P. 2012. Debt, deleveraging, and the liquidity trap: a FisherMinsky-Koo approach. Q. J. Econ. 127:1469-513

Eichengreen B, Mitchener KJ. 2003. The Great Depression as a credit boom gone wrong. Work. Pap. 137, Bank Int. Settl., Basel, Switz.

Fisher I. 1933. A debt-deflation theory of great depressions. Econometrica 1:337-57

Gorton G. 2010. Slapped by the Invisible Hand: The Panic of 2007. New York: Oxford Univ. Press

Gorton G. 2012. Misunderstanding Financial Crises: Why We Don't See Them Coming. New York: Oxford Univ. Press

Gorton G, Metrick A. 2012. Securitized banking and the run on repo. J. Financ. Econ. 104:425-51

Gorton G, Ordoñez G. 2014. Collateral crises. Am. Econ. Rev. 104:343-78

Gourinchas P-O, Obstfeld M. 2012. Stories of the twentieth century for the twenty-first. Am. Econ. J. Macroecon. 4(1):226-65

Gurley JG. 1960. The Radcliffe report and evidence. Am. Econ. Rev. 50:672-700

Haldane AG, Madouros V. 2013. The dog and the frisbee. In The Changing Policy Landscape: Proc. Symp. Spons. Fed. Reserve Bank Kansas City, pp. 109-59. Kansas City, MO: Fed. Reserve Bank Kansas City

Hawtrey RG. 1913. Good and Bad Trade: An Inquiry into the Causes of Trade Fluctuations. London: Constable

Hawtrey RG. 1919. Currency and Credit. London: Longman

Hoggarth G, Reis R, Saporta V. 2002. Costs of banking system instability: some empirical evidence. J. Bank. Finance 26:825-55

Jordà Ò. 2005. Estimation and inference of impulse responses by local projections. Am. Econ. Rev. 95:161-82

Jordà Ò, Schularick M, Taylor AM. 2011. Financial crises, credit booms, and external imbalances: 140 years of lessons. IMF Econ. Rev. 59:340-78

Jordà Ò, Schularick M, Taylor AM. 2013a. When credit bites back. J. Money Credit Bank. 45(s2):3-28

Jordà Ò, Schularick M, Taylor AM. 2013b. Sovereigns versus banks: credit, crises, and consequences. NBER Work. Pap. 19506. J. Eur. Econ. Assoc. Forthcoming

Jordà Oे, Schularick M, Taylor AM. 2014. The great mortgaging: housing finance, crises, and business cycles. NBER Work. Pap. 20501

Jordà Ò, Schularick M, Taylor AM. 2015a. Betting the house. J. Int. Econ. In press doi:10.1016/j.jinteco.2014.12.011

Jordà Ò, Schularick M, Taylor AM. 2015b. Leveraged bubbles. Unpublished manuscript, UC Davis

Jordà Ò, Taylor AM. 2011. Performance evaluation of zero net-investment strategies. NBER Work. Pap. 17150

Kaldor N. 1960. The Radcliffe report. Rev. Econ. Stat. 42:14-19

Kaminsky GL, Reinhart CM. 1999. The twin crises: the causes of banking and balance-ofpayments problems. Am. Econ. Rev. 89:473-500

Kindleberger CP. 1978. Manias, Panics, and Crashes: A History of Financial Crises. New York: Basic 
Koo RC. 2009. The Holy Grail of Macroeconomics: Lessons of Japan's Great Recession. New York: Wiley. Rev. ed.

Laeven L, Valencia F. 2008. Systemic banking crises database. Work. Pap. 08/224, Int. Monet. Fund, Washington, DC

Laeven L, Valencia F. 2012. Systemic banking crises database: an update. Work. Pap. 12/163, Int. Monet. Fund, Washington, DC

Laughlin JL. 1902. Credit. Chicago: Univ. Chicago Press

Macmillan Committee. 1931. Report of Committee on Finance and Industry. Rep. Cmd. 3897, Parliament, London

Mian A, Rao K, Sufi A. 2013. Household balance sheets, consumption, and the economic slump. Q. J. Econ. 128:1687-726

Mian A, Sufi A. 2009. The consequences of mortgage credit expansion: evidence from the U.S. mortgage default crisis. Q. J. Econ. 124:1449-96

Mian A, Sufi A. 2014. House of Debt: How They (and You) Caused the Great Recession, and How We Can Prevent It from Happening Again. Chicago: Univ. Chicago Press

Minsky H. 1986. Stabilizing an Unstable Economy. New Haven, CT: Yale Univ. Press

Obstfeld M. 2013. On keeping your powder dry: fiscal foundations of financial and price stability. Discuss. Pap. 13-E-o8, Inst. Monet. Econ. Stud., Bank Japan, Tokyo

Qian R, Reinhart CM, Rogoff KS. 2011. On graduation from default, inflation and banking crises: elusive or illusion? In NBER Macroeconomics Annual 2010, ed. D Acemoglu, M Woodford, pp. 1-36. Chicago: Univ. Chicago Press

Reinhart CM, Rogoff KS. 2009. This Time Is Different: Eight Centuries of Financial Folly. Princeton, NJ: Princeton Univ. Press

Rotemberg JJ. 2014. The Federal Reserve's abandonment of its 1923 principles. NBER Work. Pap. 20507

Schularick M, Taylor AM. 2012. Credit booms gone bust: monetary policy, leverage cycles, and financial crises, 1870-2008. Am. Econ. Rev. 102:1029-61

Taylor AM. 2014. The great leveraging. In The Social Value of the Financial Sector: Too Big to Fail or Just Too Big?, ed. VV Acharya, T Beck, DD Evanoff, GG Kaufman, R Portes, pp. 33-65. Singapore: World Sci.

Thornton H. 1939 (1802). An Enquiry into the Nature and Effects of the Paper Credit of Great Britain, ed. FA von Hayek. London: George Allen \& Unwin

Turner A. 2010. What do banks do? Why do credit booms and busts occur and what can public policy do about it? In The Future of Finance: The LSE Report, ed. A Turner, A Haldane, P Woolley, S Wadhwani, C Goodhart et al., pp. 5-86. London: London Sch. Econ. Polit. Sci.

Wolf M. 2014. The Shifts and the Shocks: What We've Learned-and Have Still to Learn-from the Financial Crisis. New York: Penguin 


\section{ENDNOTES}

1. Wolf (2014) provides a survey of the issues in the book's preface, introduction, and conclusion (for a video interview, see http://video.ft.com/3765028307001/Martin-Wolflessons-from-the-crisis/World).

2. I am indebted to my colleagues and coauthors on this project, Moritz Schularick and Òscar Jordà. I draw extensively on our joint works, which are listed in the Literature Cited (Schularick \& Taylor 2012, Jordà et al. 2011, 2013a,b, 2014, 2015a,b).

3. Of course, different financial crises may last for varying amounts of time, but the end of such an event is a concept that is not easily measured, defined, or agreed upon, and hence it is rarely used in the crisis literature.

4. Our sample construction can be compared with other major studies using panel data. Kaminsky \& Reinhart (1999) study 20 countries from 1970 to 1995, looking at crisis years for a total of 26 banking crises and 76 currency crises in the sample. Bordo et al. (2001) examine annual panels of 21 countries since 1880 and 56 countries since 1973. Cerra \& Saxena (2008) study 190 countries from 1960 to 2001. Reinhart \& Rogoff (2009, chapter 14) look at GDP for a sample of 14 major crises in the 1977-2001 period (their figure 14.4) with somewhat larger samples for other variables and some samples that include Great Depression episodes. All these other studies pooled advanced and emerging/developing countries in their data sets. Since Bordo et al. (2001), ours is the first study to go back to the nineteenth century with a comprehensive data set, starting in 1870 and running through the 2008 crisis, and restricting attention to only the experience of the advanced economies.

5. The exclusion of war periods and neighboring windows, and missing data for some countries in some years before 1900, results in an average of approximately 100 observations per country, or approximately 1,700 country-year observations total. In these, the frequency of financial crisis recessions $(n=67)$ is approximately 1 in every 25 years or $4 \%$, and the frequency of normal recessions $(n=156)$ is approximately 1 in every 11 years or $9 \%$. Of course, some financial crises occur in the sample at a greater distance than two years from a peak. They are considered isolated in that they do not coincide with a recession in this coding. This is not especially common. To see this, note that the raw frequency of financial crisis events (as in Figure 1 ) is $6 \%$, and that of financial crisis recessions is $4 \%$, as just noted. Thus, at least two-thirds of crisis events are linked to a recession in our coding. We can say "at least" because, in the nineteenth century especially, expansions are short, and thus many recession peaks are within five years of each other, yet we classify only the most proximate as financial crisis recessions. In the case of so-called isolated financial crises, those not coincident with recessions, it is also less clear what the control group is for comparisons of growth costs, so this motivates the focus here only on F's versus N's.

6. The 1959 Radcliffe Report marked a fleeting triumph of this paradigm shift, and the reader is referred to critical reviews by Gurley (1960) and Kaldor (1960). Capie (2010) provides the official history of the Bank of England's tools and practices during this period. After the 1970s, various policy regimes came and went at the Bank of England: monetarism, fixed exchange rates, inflation targeting. All of them ignored credit. 
7. Subsequently, after the 2008 global financial crisis, the BIS updated and strengthened its findings (e.g., Borio \& Drehmann 2009).

8. Shadow banks were important in the past two decades, mostly in the United States and United Kingdom. The United States has always had a significant private bond market, but for other countries, especially in continental Europe, bank-based lending has been dominant since the nineteenth century.

9. In our work, we also looked at other measures of credit and money, including total bank assets and measures of broad and narrow money. The first, bank assets, behaves similarly to credit but is typically larger (twice as big) as it includes all bank balance sheet items (e.g., loans to governments and foreign currency lending) plus interbank credit. Narrow money behaves very differently from credit and has zero predictive power for financial crises. Broad money behaves similarly to credit up to World War II, but thereafter credit diverges and grows more rapidly, reflecting the growth of leverage and later the rise of nonmonetary funding liabilities (e.g., wholesale funding). Space does not permit a detailed discussion of all these measures here, and credit has emerged as the most useful indicator in our work, and that of others, for the problems studied here.

10. There was arguably a similar hiatus in World War I in the 1914-1919 period, but this was soon reversed in the fleeting boom in the 1920 before the massive retrenchment began.

11. In other work, we have also explored the predictive ability of credit indicators to distinguish between normal and financial crisis recession events, as used in our recessionrecovery analysis above, and we find similar results, with the credit variable having strong predictive power. Owing to space limitations, these largely duplicative results, which are anyway less precise given the smaller sample of recession events within the full sample, are not reported here.

12. The saturated specification reported here is a conservative approach. Notice that including the growth rate of real loans per capita and its lags as controls stacks the odds against finding that the credit buildup during the boom (EXCESS) matters in explaining the path of the recession and subsequent recovery. We can also run the results with fewer, or no, conditioning variables and obtain qualitatively similar results. Of course, the real credit growth variable is measured differently (rate of change, contemporaneous at the peak) from the EXCESS variable (change in credit as a fraction of GDP averaged over all years in the previous business-cycle expansion phase), so these two variables are far from perfectly correlated.

13. This section draws on some ideas in the survey by Taylor (2014). 